\title{
A Minireview on Biodiscovery in Antarctic Marine Benthic Invertebrates
}

\author{
Conxita Avila ${ }^{1 *}$ and Carlos Angulo-Preckler ${ }^{1,2}$ \\ ${ }^{1}$ Department of Evolutionary Biology, Ecology, and Environmental Sciences, Biodiversity Research Institute (IrBIO), Faculty \\ of Biology, University of Barcelona, Barcelona, Spain, ${ }^{2}$ Norwegian College of Fishery Science, UiT The Arctic University \\ of Norway, Tromsø, Norway
}

Antarctic marine benthic invertebrates are an underexplored source of natural products for biodiscovery. Bioactive marine natural products from Antarctica are reviewed here for their potential use as drugs, considering the main examples in Porifera (15 species), Cnidaria (eight species), Mollusca (one species), Bryozoa (one species), Nemertea (one species), Echinodermata (six species), and Tunicata (five species). A wide variety of bioactivities are reported here, from antitumoral to antimicrobial activities, as well as against neurodegenerative diseases and others. If we aim to use their chemodiversity

OPEN ACCESS

Edited by:

Ana Rotter,

National Institute of Biology (NIB),

Slovenia

Reviewed by:

Angelina Lo Giudice,

Institute of Polar Sciences (CNR), Italy

Carmen Rizzo,

Stazione Zoologica Anton Dohrn

Napoli, Italy

*Correspondence:

Conxita Avila

conxita.avila@ub.edu

Specialty section:

This article was submitted to

Marine Biotechnology,

a section of the journal

Frontiers in Marine Science

Received: 26 March 2021

Accepted: 29 June 2021

Published: 21 July 2021

Citation:

Avila $C$ and Angulo-Preckler C (2021) A Minireview on Biodiscovery in Antarctic Marine Benthic Invertebrates.

Front. Mar. Sci. 8:686477. doi: 10.3389/fmars.2021.686477 for human benefits we must maintain the biodiversity, solving the supply problem, speeding up the process, and decreasing research costs to fully exploit the benefits of biodiscovery in Antarctic Marine Natural Products in a near future in a sustainable way.

Keywords: bioactive natural products, Porifera, Cnidaria, Mollusca, Bryozoa, Nemertea, Echinodermata, Tunicata

\section{INTRODUCTION}

Humans have used nature for obtaining food and bioactive compounds to treat diseases or as poisons for centuries. A paradigmatic example are medicinal plants. Indeed, nature has provided humankind with a wide array of bioactive compounds potentially useful as drugs against deadly diseases or as lead structures for novel synthetic drugs (Newman and Cragg, 2016). Currently, the combination of preserving biodiversity while bioprospecting natural products (chemodiversity) for human uses is a global challenge. Marine habitats comprise $71 \%$ of our planet including tropical to polar waters, and shallow to abyssal depths. This huge environment is inhabited by many different organisms adapted to the diverse physico-chemical conditions found in there. Marine ecosystems include many unique habitats hosting species and chemicals still vastly unknown (including novel compounds' classes and chemical skeletons), as well as unique phyla that never evolved to colonize land. The variety of chemicals found in these organisms constitutes what we call chemodiversity. These marine natural products (MNPs) are likely the result of evolutionary pressures, such as predation or competition (Avila et al., 2008), and have been shaped into structurally diverse compounds with specific biological and ecological activities rarely found in terrestrial organisms (Höller et al., 2000; Carroll et al., 2020). Chances of finding new drug candidates or relevant bioactive compounds in the ocean are especially high. However, marine sources are much less explored than terrestrial organisms and only $1 \%$ of recorded marine species have had their chemical composition analyzed, even if ca. $10 \%$ of the 145,000 natural substances described to date come from marine organisms (Núñez-Pons and Avila, 2015). Therefore, the discovery potentialities of novel MNPs and their putative applications remain wide open. Currently, more than 35,000 
MNPs are known from macro- and microorganisms (MarinLit database ${ }^{1}$ ), some of them being in advanced clinical development as anticancer drugs, and many more being tested for the treatment of pain, neurodegenerative disorders, tuberculosis, AIDS, malaria, and many other diseases, as well as for their use in cosmetics, nutriceuticals and food industries (Kim and Wijesekara, 2010; Suarez-Jimenez et al., 2012; Fan et al., 2014; Martins et al., 2014; Tripathi et al., 2014).

Research on MNPs is based on multidisciplinary collaboration between scientists from different fields, such as chemical ecology, chemistry, biosynthesis, pharmacology, molecular biology, genomics, metabolomics, and others. Furthermore, the new techniques and methodologies used in the isolation and chemical characterization of compounds are rapidly improving the biodiscovery path. Over the years, bioactive MNPs from different oceans have found many pharmaceutical applications, as said above, ranging from antitumoral to antimicrobials. Some drug examples include the nucleosides isolated in the 1950s from a Caribbean sponge, later used as scaffolds for commercial antiviral drugs [Ara-A $\left(\right.$ Acyclovir $\left.^{\circledR}\right)$ or Ara-C], the analgesic $\omega$-conotoxin analog ziconotide (Prialt ${ }^{\circledR}$ ) from a Conus mollusc used for chronic pain, ecteinascidin 743 (Yondelis $^{\circledR}$ ) from a tunicate for cancer chemotherapy (sarcoma), and eribulin mesylate $\left(\right.$ Halaven $\left.^{\circledR}\right)$, a derivative of halichondrin B from the cold-water sponge Halichondria okadai as an anticancer drug (Gerwick and Moore, 2012; Jaspars et al., 2016; Giordano et al., 2018). Many MNPs are commonly used in food industry as stabilizers and food additives, like the carrageenans from red seaweeds (Carragelose ${ }^{\circledast}$ ), also employed in antiviral sprays, or carotenoids, used as food colorants, additives, and nutraceuticals (Jaspars et al., 2016). The use of new enzymes is also of great interest for many industrial processes, like the proteases, amylases, cellulases, carboxymethylcellulases, xylanases,..., for their use in the production of pharmaceuticals, foods, beverages, confectionery, paper, textile and leather processing, and waste-water treatment (Jaspars et al., 2016; Giordano et al., 2018). Cosmetics, on the other hand, include MNPs used as sun protectors, face, skin, and hair care products, such as Abyssine ${ }^{\circledR}$, Depollutine $^{\circledR}$, Grevilline ${ }^{\circledR}$, RefirMAR ${ }^{\circledR}$, Resilience ${ }^{\circledR}$, SeaCode $^{\circledR}$, XCELL-30 ${ }^{\circledR}$, and others (Martins et al., 2014; Reen et al., 2015). In fact, the cosmetic industry, like Elemis (The Steiner Group, London, United Kingdom), La Prairie (Beiersdorf, Montreux, Switzerland), Crème de la Mer (Estée Lauder, New York, NY, United States), Blue Therapy (Biotherm, Tours, France), is constantly innovating using marine-derived bioactive compounds (Martins et al., 2014).

Antarctic waters harbor about $4 \%$ approximately of the currently known marine invertebrate species, while a huge amount of species are considered to be still unknown (Arrieta et al., 2010; Griffiths, 2010; Ronowicz et al., 2019). The environmental conditions there are extreme, with cold, constant temperatures and a seasonal light regime, with many species being endemic to these habitats, representing a huge, still unexplored biodiversity. The South Ocean therefore holds a huge potential for MNPs biodiscovery, based on both their

${ }^{1}$ http://pubs.rsc.org/marinlit/ untapped bio- and chemodiversity. In part, the scarce current knowledge on the topic is due to the well-known difficulties in sampling and studying Antarctic organisms (Avila et al., 2008). Nevertheless, Antarctic bioprospecting is being developed currently by different groups using different methods and strategies (e.g., Avila, 2016a,b; Soldatou and Baker, 2017) although the topic has not been reported sufficiently in the general literature (e.g., Thomas et al., 2008). Some of the MNPs found so far in Antarctica are potentially useful for humans, as precursors of active molecules to design new drugs with a pharmacologic potential, as antimicrobials, or as antifouling, or have been tested within extracts but are not identified yet (e.g., Moles et al., 2014; Angulo-Preckler et al., 2017; Sacristán-Soriano et al., 2017). We review here the current status of biodiscovery in Antarctic marine benthic invertebrates.

\section{THE CONCEPT OF BIOPROSPECTING}

"Bioprospecting" (or biodiversity prospecting) is the exploitation of natural richness by searching for unknown or not studied organisms holding singular small molecules, macromolecules, and biochemical and genetic heritage, which may possess biological activities (Eisner, 1990; Jabour-Green and Nicol, 2003). These biological activities may be further developed into commercially valuable products for the agriculture (Beattie et al., 2011; Pandey and Yarzábal, 2019), aquaculture (Mazarrasa et al., 2014; Pascoal et al., 2020), bioremediation (Abida et al., 2013; Mazarrasa et al., 2014), cosmetic (Upadhyay et al., 2016; Gupta et al., 2019), nanotechnology (Mazarrasa et al., 2014; Cushnie et al., 2020), and/or pharmaceutical markets (Newman and Cragg, 2016; Pandey and Yarzábal, 2019). Usually biodiscovery starts with the collection of biological samples, targeting a reduced amount of biomass, followed by a bioactivity screening in order to select and further purify and identify the bioactive molecules, as well as to further synthesize them, when possible. The next steps include the in vitro, in vivo, and clinical assays, and the eventual progress to the market according to the pertinent regulatory issues. In the pharmaceutical industry, for example, almost one third of all small-molecule drugs approved by the U.S. Food and Drug Administration (FDA) between 1981 and 2014 were either NPs or compounds directly derived from natural products (Newman and Cragg, 2016).

When bioprospecting marine benthic invertebrates, we look for bioactive NPs. NPs are a small organic secondary metabolites $(<3000 \mathrm{Da})$ synthetized by all organisms in response to different external stimuli. Because MNPs are produced under unique environmental conditions in the oceans, they are characterized by uncommon functional groups (isonitrile, dichloramine, isocyanate, and halogenated functional groups, among others) and peculiar structures, often with no analogs in terrestrial NPs (Imhoff et al., 2011; Rocha-Martin et al., 2014). NPs present many advantages over non-natural compounds, like a huge chemical diversity, biochemical specificity, binding efficiency and a strong ability to interact with biological targets. Therefore, NPs are considered more suitable for biological applications (such as anti-tumor, anti-proliferative, antibiotic, 
anti-infective, antifungal, antiviral, antiparasitic, antihelmintic, photoprotective) and potentially relevant lead structures (Kayser et al., 2003; Nishimura et al., 2010; Waters et al., 2010; Mayer et al., 2010, 2013; Martins et al., 2014; Buenz et al., 2018). In fact, NPs account for most of the clinically approved drugs (Newman and Cragg, 2012; Patridge et al., 2016) and were mainly described from bacteria, fungi, and plants, while marine organisms were investigated only in recent decades (Bérdy, 2012; Gerwick and Fenner, 2013). Currently, the number of MNPs described has rised to more than 35000 (MarinLit database ${ }^{2}$ ). Among them, a part of the examples cited above, ca. 30 MNPs are in clinical trials, with more than 20 being classified as anticancer, and a few more for schizophrenia and Alzheimer's diseases, as well as for chronic pain treatment ${ }^{3}$ and therefore, the number of MNPs is expected to increase soon (Jaspars et al., 2016). Regarding Antarctic organisms, the bioactivity levels of MNPs have been reported to be comparable to those recorded in temperate marine environments, although only about $3 \%$ of the discovered MNPs originate from the polar regions (Lebar et al., 2007; Avila et al., 2008; Leal et al., 2012; Soldatou and Baker, 2017), and thus, more data are needed to draw general conclusions. According to the biodiversity data, a hidden treasure of bioactive MNPs is still waiting to be discovered in Antarctica, and considering the peculiar characteristics of the organisms living there, expectations are high.

\section{PORIFERA}

Sponges comprise some of the most abundant macroinvertebrates of Antarctic benthic communities, serving both as substrates for colonizing epibionts and endobionts, and as food sources for predators (McClintock et al., 2005). Antarctic sponges are a valuable source of biologically active compounds with drug potential, accounting for almost half of the pharmacologically active compounds of marine origin (Hu et al., 2011; Leal et al., 2012). Several Antarctic sponge species possess extracts with a wide range of bioactivities, such as cytotoxicity, hemolytic activity, antialgal activity, a-amylase activity, cholinesterase activities, antibacterial activity, and antifungal activity (Turk et al., 2013) (Table 1). One of the most prominent is the genus Latrunculia, showing hemolysis, inhibition of acetylcholinesterase, cytotoxicity toward normal and transformed cells, and growth inhibition of laboratory, commensal, and clinically and ecologically relevant bacteria (Turk et al., 2013). The brominated pyrroloiminoquinone alkaloids isolated from methanol extracts of two specimens of Latrunculia sp. demonstrated for the first time to be reversible competitive inhibitors of cholinesterases, with $\mathrm{Ki}$ for electric eel acetylcholinesterase of 1.6-15.0 $\mu \mathrm{M}$, for recombinant human acetylcholinesterase of $22.8-98.0 \mu \mathrm{M}$, and for horse serum butyrylcholinesterase of 5.0-76.0 $\mu \mathrm{M}$. The most active compound, discorhabdin G (Figure 1), had no detectable undesirable effects on neuromuscular transmission and skeletal

\footnotetext{
${ }^{2}$ http://pubs.rsc.org/marinlit

${ }^{3}$ https://www.midwestern.edu/departments/marinepharmacology/clinicalpipeline.xml
}

muscle function (Botić et al., 2017). The pigment epinardin C (Figure 1), proved strongly active, albeit with poor resistant index against L1210 and doxorubicin-resistant L1210/DX murine lymphocytic leukemia cells in vitro (D'Ambrosio et al., 1996). Epinardin $\mathrm{C}$ was isolated from an undetermined demosponge and it differs from members of the discorhabdin/prianosin family in having an allylic alcohol functionality in place of the enone system, being compatible with the genus Latrunculia. Similarly, the extracts of L. biformis showed potent in vitro anticancer activity (Li et al., 2020b), with two discorhabdin-type alkaloids, tridiscorhabdin (Figure 1) and didiscorhabdin isolated from it. Only tridiscorhabdin exhibited strong cytotoxic activity against the human colon cancer cell line HCT-116 $\left(\mathrm{IC}_{50}\right.$ value $0.31 \mu \mathrm{M})$ ( $\mathrm{Li}$ et al., 2020b). Further, (-)-(1R,2R,6R,8S,6'S)discorhabdin B dimer and (-)-(1S,2R,6R,8S,6'S)-discorhabdin $\mathrm{B}$ dimer showed significant in vitro anticancer activity against the same cell line (HCT-116), with $\mathrm{IC}_{50}$ values of 0.16 and $2.01 \mu \mathrm{M}$, respectively (Li et al., 2020a). Compared to monomeric discorhabdins, dimeric discorhabdins are very rare in nature. Moreover, a molecular networking approach combined with a bioactivity-guided isolation led to the targeted isolation of the pyrroloiminoquinone, tsitsikammamine A (Figure 1) and its analog 16,17-dehydrotsitsikammamine A (Li et al., 2018). Both tsitsikammamines and discorhabdins show potent anticancer activities in vitro and further potential anticancer activity was assessed with a virtual approach by molecular modeling for the tsitsikammamines (Li et al., 2018). L. biformis is an excellent source of chemically diverse discorhabdin alkaloids. (-)-discorhabdin L (Figure 1), (-)-1-acetyl-discorhabdin L, and (+)-1-octacosatrienoyl-discorhabdin L, showed promising anticancer activity with $\mathrm{IC}_{50}$ values of $0.94,2.71$, and $34.0 \mu \mathrm{M}$, respectively (Li et al., 2019). These compounds were docked to the active sites of two anticancer targets, topoisomerase I-II and indoleamine 2,3-dioxygenase (IDO1), revealing the binding potential of discorhabdins to these proteins ( $\mathrm{Li}$ et al., 2019). Furthermore, Latrunculia sp. yielded a new antibacterial pyrroloiminoquinone, discorhabdin R (Figure 1) with antibacterial activity against Gram + (Staphylococcus aureus, Micrococcus luteus) and Gram - (Serratia marcescens, Escherichia coli) bacteria (Ford and Capon, 2000).

Membranolides C and D (Figure 1) from the sponge Dendrilla membranosa possess carboxylic acid functional groups and display Gram - antibiotic and antifungal activities (Ankisetty et al., 2004). The 9,11-dihydrogracilin A (DHG) and membranolide (Figure 1) from D. membranosa both inhibited the growth of Bacillus subtilis at $100 \mu \mathrm{g} /$ disk and membranolide was also mildly active against $S$. aureus (Molinski and Faulkner, 1987). DHG induced apoptosis in human peripheral blood mononuclear cells (PBMC) (Ciaglia et al., 2017). In addition, DHG possesses promising antiinflammatory properties both in vitro and in vivo. These effects are accompanied by DHG down-regulation of NF-kB, STAT, and ERK phosphorylation at further stages (Ciaglia et al., 2017). The antimicrobial activity of the extracts of this sponge against $S$. aureus, Vibrio anguillarum, and Beneckea harveyi (100 $\mu \mathrm{g} / \mathrm{disk})$, was due to 4,5,8-trihydroxyquinoline-2carboxylic acid (Molinski and Faulkner, 1988). Darwinolide A 
TABLE 1 | Brief summary of bioactive natural products from Antarctic marine benthic invertebrates.

\begin{tabular}{|c|c|c|c|c|c|c|}
\hline $\begin{array}{l}\text { Phylum } \\
\text { (spp \#) }\end{array}$ & Order/Class & Species & Compound & Activity & Locality & References \\
\hline
\end{tabular}

Porifera (15) Demospongiae Crella sp. Norselic acid A-E

\section{Antibiotic activity against
methicillin-resistant Staphylococcus \\ aureus (MRSA), methicillin-sensitive \\ S. aureus (MSSA), \\ vancomycinresistant Enterococcus \\ faecium (VRE), and Candida \\ albicans. Active against Leishmania parasite}

Demospongia

Demospongiae

Dendrilla antarctica Tetrahydroaplysulphurin-1, Membranoids B, D, G

Dendrilla antarctica Aplysulphurin,

Membranolide, Dendrillins B-D

Demospongiae

Demospongiae

Demospongiae

Demospongiae

Demospongiae

Demospongiae

Demospongiae

Demospongiae

Demospongiae

Demospongiae

Demospongiae

Demospongiae

Demospongiae

Demospongiae

Demospongiae

Demospongiae
Dendrilla

membranosa

Dendrilla

membranosa

Dendrilla

membranosa

Dendrilla

membranosa

Inflatella

coelosphaeroides

Isodictya antarctica

Ceramide

Erebusinonamine

Isodictya erinacea$$
\text { Ereb }
$$

Erebusinone, Erinacin

Kirkpatrickia

variolosa

Kirkpatrickia

variolosa

Kirkpatrickia

variolosa

Latrunculia apicalis

Darwinolide

Dihydrogracilin A (DHG)

9,11-dihydrogracilin A, Membranolide

4,5,8-

trihydroxyquinolirihydroxylic acid

Friomaramide

Themaramide

Latrunculia biformis

iscorhabdin, Didiscorhabdins

Latrunculia biformis Tsitsikammamines, Discorhabdins

Latrunculia sp.

Discorhabdin R

Latrunculia spp.

Discorhabdins B, L, G, and 3-dihydro-7,8dehydrodiscorhabdin $\mathrm{C}$

Phorbas areolatus human colon cancer cell line 19-episuberitenone B, Isoxaspirosuberitenone, Suberitenone A-B, Oxaspirosuberitenone

Inhibitors of Leishmania parasite

Bioactive against Leishmania donovani, Plasmodium falciparum, and methicillin-resistant Staphylococcus aureus (MRSA) Inhibits methicillin-resistant Staphylococcus aureus biofilm Immuno-modulatory and anti-Inflammatory

Inhibits the growth of Bacillus subtilis and Staphylococcus aureus Antimicrobial to Staphylococcus aureus, Vibrio anguillarum, Beneckea harveyi (B-392) Inhibits Plasmodium falciparum liver-stage development

Antimicrobial to Staphylococcus aureus, methicillin-resistant S. aureus (MRSA), Escherichia faecium, and Candida albicans

Cytotoxic against mouse lyphoblastoid cell line (L5178Y). Antimicrobial to Escherichia coli, Staphylococcus aureus, and S. epidermidis Inhibits protein tyrosine kinase (PTK) and protein kinase C (PKC)

Cytotoxic against the P388 leukemia cell line Inhibits Saccharomyces cerevisiae growth. Active against HCT 116 cell line and P388 leukemia

Antibiotic against Gram + and Gram - bacteria

Strong cytotoxic activity against HCT-116

Anticancer activity against six human cancer cell lines Antibacterial activity

Cholinesterase inhibitors (AD)

Anvers Island

N.A.

von Salm et al. (2016)

McMurdo Sound

Ciaglia et al. (2017)

N.A.

Antarctic waters

Molinski and Faulkner (1987)

Molinski and

Faulkner (1988)

Knestrick et al. (2019)

Palmer station Park (2004)

McMurdo Sound Moon et al. (2000, 1998)

McMurdo Sound Jayatilake et al. (1995)

McMurdo Sound Trimurtulu et al. (1994)

McMurdo Sound Perry et al. (1994)

McMurdo Sound Yang et al. (1995)

Weddell Sea Li et al., 2020a,b

Weddell Sea Li et al. (2018,

2019)

Prydz Bay $\quad$ Ford and Capon (2000)

Antarctic Peninsula Botić et al. (2017)

Cytotoxicity against lung (A549), breast (MCF-7), colon (HT29), and liver (HepG2) tumor cell lines.

Antimicrobial activity against methicillin-resistant Staphylococcus aureus (MRSA) 
TABLE 1 | Continued

\begin{tabular}{|c|c|c|c|c|c|c|}
\hline $\begin{array}{l}\text { Phylum } \\
\text { (spp \#) }\end{array}$ & Order/Class & Species & Compound & Activity & Locality & References \\
\hline & Demospongiae & Suberites sp. & Suberitenone B & $\begin{array}{l}\text { Inhibits the cholesteryl ester } \\
\text { transfer protein (CETP) }\end{array}$ & King George Island & Shin et al. (1995) \\
\hline & Demospongiae & $\begin{array}{l}\text { Undetermined } \\
\text { deep-water green } \\
\text { demosponges }\end{array}$ & Epinardins A-D & $\begin{array}{l}\text { Epinardin C cytotoxic toward } \\
\text { doxorubicin-resistant L121O/DX } \\
\text { tumoural cells in vitro }\end{array}$ & Crozet Islands & $\begin{array}{l}\text { D'Ambrosio et al. } \\
\text { (1996) }\end{array}$ \\
\hline & Unidentified & Unidentified & $\begin{array}{l}\text { Non-nitrogenous } \\
\text { eudesmane }\end{array}$ & $\begin{array}{l}\text { Antibiotic activity against } \\
\text { Staphylococcus aureus }\end{array}$ & Prydz Bay & Urban et al. (1995) \\
\hline & Calcarea & $\begin{array}{l}\text { Leucetta } \\
\text { leptorhapsi }\end{array}$ & Rhapsamine & $\begin{array}{l}\text { Cytotoxicity against KB } \\
\text { nasopharyngeal cell line }\end{array}$ & McMurdo Sound & $\begin{array}{l}\text { Jayatilake et al. } \\
\text { (1997) }\end{array}$ \\
\hline \multirow[t]{9}{*}{ Cnidaria (8) } & Octocorallia & Acanthogorgia laxa & Azulenoid sesquiterpenes & Antifouling activity & $\begin{array}{l}\text { South Shetland } \\
\text { Islands }\end{array}$ & $\begin{array}{l}\text { Patiño-Cano et al. } \\
\text { (2018) }\end{array}$ \\
\hline & Octocorallia & $\begin{array}{l}\text { Ainigmaptilon } \\
\text { antarcticum }\end{array}$ & Ainigmaptilones A & Antifouling and antibacterial activity & $\begin{array}{l}\text { Eastern Weddell } \\
\text { Sea }\end{array}$ & $\begin{array}{l}\text { Iken and Baker } \\
\text { (2003) }\end{array}$ \\
\hline & Octocorallia & Alcyonium paessleri & Alcyopterosins A-O & $\begin{array}{l}\text { Cytotoxic against human tumor cell } \\
\text { lines }\end{array}$ & $\begin{array}{l}\text { South Georgia } \\
\text { Islands }\end{array}$ & $\begin{array}{l}\text { Palermo et al. } \\
(2000)\end{array}$ \\
\hline & & & Paesslerins A-B & $\begin{array}{l}\text { Cytotoxic against human tumor cell } \\
\text { lines }\end{array}$ & $\begin{array}{l}\text { South Georgia } \\
\text { Islands }\end{array}$ & $\begin{array}{l}\text { Rodriguez-Brasco } \\
\text { et al. (2001) }\end{array}$ \\
\hline & Octocorallia & $\begin{array}{l}\text { Anthomastus } \\
\text { bathyproctus }\end{array}$ & Steroids $2-5$ & $\begin{array}{l}\text { Cytotoxicity against human tumor } \\
\text { cell lines }\end{array}$ & $\begin{array}{l}\text { South Shetland } \\
\text { Islands }\end{array}$ & $\begin{array}{l}\text { Mellado et al. } \\
\text { (2005) }\end{array}$ \\
\hline & Octocorallia & $\begin{array}{l}\text { Anthoptilum } \\
\text { grandiflorum }\end{array}$ & Bathyptilones A-C & $\begin{array}{l}\text { Cytotoxicity toward the neurogenic } \\
\text { mammalian cell line Ntera-2 }\end{array}$ & Scotia Arc & $\begin{array}{l}\text { Thomas et al. } \\
\text { (2019) }\end{array}$ \\
\hline & Octocorallia & $\begin{array}{l}\text { Dasystenella } \\
\text { acanthina }\end{array}$ & Polyoxygenated steroids & $\begin{array}{l}\text { Growth inhibitors of several human } \\
\text { tumor cell lines. Cytostatic and } \\
\text { cytotoxic on selected tumor cell } \\
\text { lines }\end{array}$ & $\begin{array}{l}\text { Eastern Weddell } \\
\text { Sea }\end{array}$ & $\begin{array}{l}\text { Mellado et al. } \\
(2004)\end{array}$ \\
\hline & Octocorallia & $\begin{array}{l}\text { Plumarella } \\
\text { delicatissima }\end{array}$ & $\begin{array}{l}\text { Keikipukalides B-E, } \\
\text { Pukalide aldehyde, } \\
\text { Norditerpenoid } \\
\text { ineleganolide }\end{array}$ & $\begin{array}{l}\text { Activity against Leishmania } \\
\text { donovani }\end{array}$ & Falkland Islands & $\begin{array}{l}\text { Thomas et al. } \\
\text { (2018) }\end{array}$ \\
\hline & Octocorallia & $\begin{array}{l}\text { Unidentified soft } \\
\text { coral }\end{array}$ & Shagenes A-B & $\begin{array}{l}\text { Activity against Leishmania } \\
\text { donovani }\end{array}$ & Scotia Arc & $\begin{array}{l}\text { von Salm et al. } \\
(2014)\end{array}$ \\
\hline Mollusca (1) & Gastropoda & $\begin{array}{l}\text { Doris } \\
\text { kerguelenensis }\end{array}$ & Palmadorins & Inhibits human erythroleukemia & $\begin{array}{l}\text { Ross Sea, Antarctic } \\
\text { Pen. }\end{array}$ & $\begin{array}{l}\text { Maschek et al. } \\
\text { (2012) }\end{array}$ \\
\hline Bryozoa (1) & Cheilostomata & $\begin{array}{l}\text { Aspidostoma } \\
\text { giganteum }\end{array}$ & Aspidostomide E & $\begin{array}{l}\text { Active against the } 786-0 \text { renal } \\
\text { carcinoma cell line }\end{array}$ & $\begin{array}{l}\text { Patagonia } \\
\text { (Argentina) }\end{array}$ & $\begin{array}{l}\text { Patiño-Cano et al. } \\
\text { (2014) }\end{array}$ \\
\hline Nemertea (1) & Heteronemertea & $\begin{array}{l}\text { Parborlasia } \\
\text { corrugatus }\end{array}$ & Parbolysins & Cytotoxic and hemolytic activity & $\begin{array}{l}\text { Ross Sea, Antarctic } \\
\text { Pen. }\end{array}$ & $\begin{array}{l}\text { Göransson et al. } \\
\text { (2019) }\end{array}$ \\
\hline \multirow[t]{6}{*}{$\begin{array}{l}\text { Echinodermata } \\
\text { (6) }\end{array}$} & Asteroidea & $\begin{array}{l}\text { Acodontaster } \\
\text { conspicuus }\end{array}$ & $\begin{array}{l}\text { Polyhydroxylated steroids, } \\
\text { Steroidal oligoglycosides }\end{array}$ & Antimicrobial activity & McMurdo Sound & $\begin{array}{l}\text { De Marino et al. } \\
\text { (1997b) }\end{array}$ \\
\hline & Asteroidea & Diplasterias brucei & Diplasteriosides A-B & $\begin{array}{l}\text { Cytotoxic against different human } \\
\text { cancer cell lines }\end{array}$ & Ross Sea & $\begin{array}{l}\text { Ivanchina et al. } \\
\text { (2011) }\end{array}$ \\
\hline & Asteroidea & Henricia sp. & $\begin{array}{l}\text { Asterosaponins, Glicosides } \\
\text { of polyhydroxysteroids, } \\
\text { Polyhydroxylated steroids }\end{array}$ & $\begin{array}{l}\text { Cytotoxic against human } \\
\text { broncopulmonary } \\
\text { non-small-cell-lung-carcinoma cells } \\
\text { (NSCLC-N6) }\end{array}$ & Tethys Bay & lorizzi et al. (1996) \\
\hline & Asteroidea & Unidentified & $\begin{array}{l}\text { Asterasterol A-C, } \\
\text { Asteriidosides A-L }\end{array}$ & $\begin{array}{l}\text { Cytotoxic against human } \\
\text { broncopulmonary } \\
\text { non-small-cell-lung-carcinoma cells } \\
\text { (NSCLC-N6) }\end{array}$ & Tethys Bay & $\begin{array}{l}\text { De Marino et al. } \\
(1997 a, 1998)\end{array}$ \\
\hline & Holothuroidea & $\begin{array}{l}\text { Staurocucumis } \\
\text { liouvillei }\end{array}$ & Liouvillosides A-B & $\begin{array}{l}\text { Virucidal against herpes simplex } \\
\text { virus type } 1(\mathrm{HSV}-1)\end{array}$ & $\begin{array}{l}\text { South Georgia } \\
\text { Islands }\end{array}$ & Maier et al. (2001) \\
\hline & Ophiuroidea & Ophiosparte gigas & $\begin{array}{l}\text { Sulphated } \\
\text { polyhydroxysteroids }\end{array}$ & $\begin{array}{l}\text { Cylotoxic activity, cytoprotective } \\
\text { against HIV-1 }\end{array}$ & Ross Sea & D'Auria et al. (1993) \\
\hline \multirow[t]{2}{*}{ Tunicata (5) } & Ascidiacea & Aplidium cyaneum & Aplicyanins A-F & Cytotoxic and antimitotic activities & Weddell sea & Reyes et al. (2008) \\
\hline & Ascidiacea & $\begin{array}{l}\text { Aplidium } \\
\text { meridianum }\end{array}$ & Meridianins A-E & $\begin{array}{l}\text { Cytotoxicity toward murine tumor } \\
\text { cell lines, against Alzheimer disease }\end{array}$ & $\begin{array}{l}\text { South Georgia } \\
\text { Islands, Antarctic } \\
\text { Pen. }\end{array}$ & $\begin{array}{l}\text { Franco et al. (1998); } \\
\text { Llorach-Parés et al. } \\
\text { (2017) }\end{array}$ \\
\hline
\end{tabular}


TABLE 1 | Continued

\begin{tabular}{|c|c|c|c|c|c|c|}
\hline $\begin{array}{l}\text { Phylum } \\
\text { (spp \#) }\end{array}$ & Order/Class & Species & Compound & Activity & Locality & References \\
\hline & Ascidiacea & Aplidium sp. & Rossinones A-B & $\begin{array}{l}\text { Antiinflammatory, antiviral and } \\
\text { antiproliferative activities }\end{array}$ & Ross Sea & $\begin{array}{l}\text { Appleton et al. } \\
\text { (2009) }\end{array}$ \\
\hline & Ascidiacea & $\begin{array}{l}\text { Synoicum } \\
\text { adareanum }\end{array}$ & Palmerolides A, C, D-G & V-ATPase inhibitors & Anvers Island & $\begin{array}{l}\text { Diyabalanage et al. } \\
\text { (2006); Noguez } \\
\text { et al. (2011) }\end{array}$ \\
\hline & & & $\begin{array}{l}\text { Abeohyousterone, } \\
\text { Hyousterones A, C }\end{array}$ & Cytotoxic & Antarctic Peninsula & Miyata et al. (2007) \\
\hline & Thaliacea & Salpa thompsoni & Fatty acids and sterols & Hemolytic activity & $\begin{array}{l}\text { South Orkney } \\
\text { Islands }\end{array}$ & Mimura et al. (1986) \\
\hline
\end{tabular}

(Figure 1), a diterpenoid from Dendrilla antarctica (previously D. membranosa) showed potential as a scaffold for methicillinresistant S. aureus (MRSA) (von Salm et al., 2016). This is a chemically rich sponge, being a prolific source of highly oxidized diterpenoids with moderate antibiotic and antifungal activities against S. aureus, E. coli, and Candida albicans (Molinski and Faulkner, 1987). Bioactivities against infectious disease models including pathogens that cause leishmaniasis, malaria, and MRSA infections were also found (Bory et al., 2020). Four more diterpenes, tetrahydroaplysulphurin-1 (Figure 1), as well as membranoids B (Figure 1), D, and G, displayed low micromolar activity against Leishmania donovani with no discernible cytotoxicity against uninfected J774A.1 cells (Shilling et al., 2020).

Friomaramide (Figure 1), a highly modified hexapeptide isolated from the sponge Inflatella coelosphaeroides blocks $>90 \%$ of Plasmodium falciparum liver-stage parasite development at $6.1 \mu \mathrm{M}$ (Knestrick et al., 2019). The Antarctic red sponge Kirkpatrickia variolosa presents a resveratrol triacetate $\left(3,4^{\prime}, 5\right.$ triacetoxystilbene) (Jayatilake et al., 1995). Stilbenes exhibit a variety of biological and pharmacological activities including protein tyrosine kinase (PTK) and protein kinase $\mathrm{C}$ (PKC) inhibitory effects (Jayatilake et al., 1995), but this compound has not yet been tested. Also in K. variolosa, variolins display cytotoxic, antiviral, and antifungal properties (Perry et al., 1994; Trimurtulu et al., 1994). Variolin A (Figure 1) showed weak in vitro activity against the $\mathrm{P} 388$ cell line $\left(\mathrm{IC}_{50}=3.8 \mu \mathrm{g} / \mathrm{mL}\right)$. $\mathrm{N}\left(3^{\prime}\right)$-Methyl tetrahydrovariolin B inhibited the growth of Saccharomyces cerevisiae $(2 \mathrm{mg} / \mathrm{mL})$, showed in vitro activity against the HCT 116 cell line $\left(\mathrm{IC}_{50}=0.48 \mu \mathrm{g} / \mathrm{mL}\right.$ ), and modest in vivo activity against P388 leukemia (at $10 \mathrm{mg} / \mathrm{Kg}$ ) (Trimurtulu et al., 1994). Variolin B, with an $\mathrm{IC}_{50}$ of $210 \mathrm{ng} / \mathrm{mL}$ against P388, was also effective against Herpes simplex Type I (Perry et al., 1994). Variolin B is a pyridopyrrolopyrimidine alkaloid with antitumor and antiviral properties.

All of the norselic acids (A-E) from the encrusting, bright red sponge Crella sp. display activity against the Leishmania parasite at low micromolar concentration. Norselic acid A (Figure 1) displays antibiotic activity against methicillin-resistant $S$. aureus (MRSA), methicillin-sensitive $S$. aureus (MSSA), vancomycinresistant Enterococcus faecium (VRE), and C. albicans, and it is also active against the Leishmania parasite with modest antiinfective properties (Ma et al., 2009).
Suberitenone B (Figure 1) inhibits the cholesteryl ester transfer protein (CETP), which mediates the transfer of cholesteryl ester and triglyceride between high-density lipoproteins and low-density lipoproteins (Shin et al., 1995). CETP inhibition is considered to be a good target for the development of an effective agent for atherosclerotic diseases. Three suberitane derivatives, isosuberitenone B, 19episuberitenone $\mathrm{B}$, and isoxaspirosuberitenone are found in the sponge Phorbas areolatus, together with suberitenones A and B, and oxaspirosuberitenone (Figure 1) (Solanki et al., 2018). Oxaspirosuberitenone displayed significant antimicrobial activity against MRSA at the highest concentration tested (160 $\mu \mathrm{M})$. While all five compounds displayed moderate cytotoxicity against the HepG2, HT-29, and MCF-7 cell lines, only isosuberitenone B and 19-suberitenone B showed significant activity against the A549, HepG2, HT-29, and MCF-7 tumor cell lines (Solanki et al., 2018).

Erebusinone (Figure 1) and erinacine are found in Isodictya erinacea. Erinacine has shown cytotoxicity $\left(\mathrm{LD}_{50} 50 \mu \mathrm{g} / \mathrm{mL}\right.$ ) against L5178Y mouse lymphoblastoid cells (Moon et al., 2000), while erebusinone together with a ceramide and erebusinonamine from Isodictya antarctica showed modest antimicrobial activity against $S$. aureus, methicillin-resistant S. aureus (MRSA), E. faecium, and C. albicans (Park, 2004). Further, an unidentified sponge yielded a sesquiterpene alcohol, a non-nitrogenous eudesmane with antibiotic activity against the Gram + bacteria S. aureus (Urban et al., 1995). Finally, rhapsamine (Figure 1), a linear C28 polyene from the only calcareous sponge studied, Leucetta leptorhapsis, displays a $\mathrm{LC}_{50}$ of $1.8 \mu \mathrm{M}$ in the KB nasopharyngeal cell line, while in the NCI 60 cell-line panel displays a similar level of cytotoxicity with little selectivity (Jayatilake et al., 1997).

\section{CNIDARIA}

NPs from Antarctic cnidarians are only known from octocorals so far, including a series of sesquiterpenes and polyoxygenated steroids isolated from Alcyonium paessleri (Palermo et al., 2000; Rodriguez-Brasco et al., 2001), Ainigmaptilon antarcticus (Iken and Baker, 2003), and Dasystenella acanthina (Gavagnin et al., 2003) (Table 1). Of the latter, all steroids show significant activities as growth inhibitors of several human 


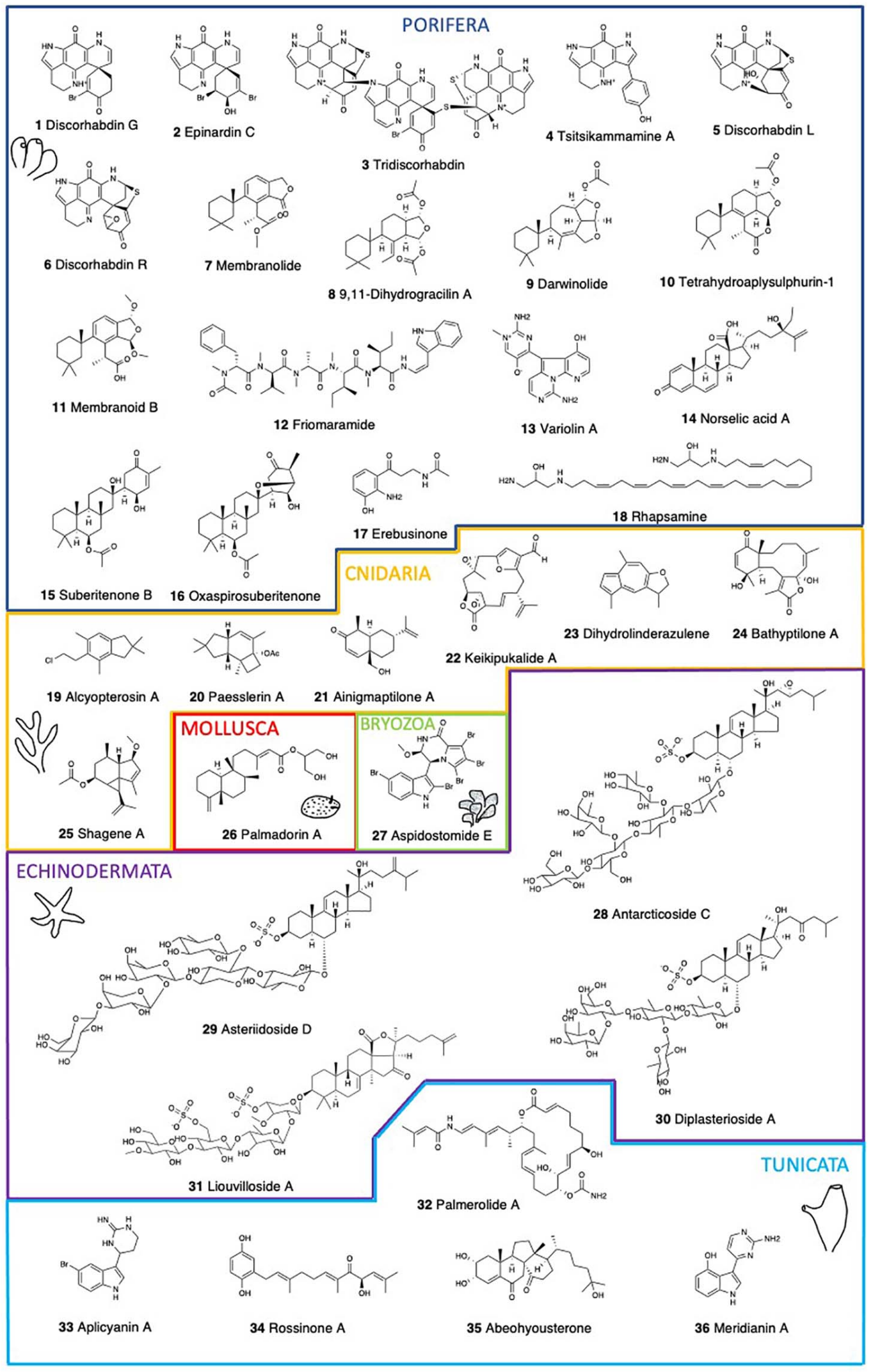

FIGURE 1 | Chemical structure of the main bioactive compounds described in Antarctic marine benthic invertebrates. 
tumor cell lines (Mellado et al., 2004). Higher levels of activity were observed against the cell lines LN-caP (prostate carcinoma), and K-562 (chronic myelogenous leukemia), with most compounds displaying $\mathrm{GI}_{50}$ values $<2 \mu \mathrm{g} / \mathrm{mL}$ (Mellado et al., 2004). In addition, these steroids showed cytostatic effects and are cytotoxic against one or two cell lines, except $3 \alpha, 11 \alpha$-diacetoxy-25-hydroxycholest-4-en-6-one, that was active against seven of the assayed cell lines, including DU-145 (prostate carcinoma), IGROV (ovarian adenocarcinoma), SK-MEL-28 (melanoma), PANC1 (pancreas carcinoma), and LOVO (colon adenocarcinoma) (Mellado et al., 2004).

The first illudalane sesquiterpenoids isolated from the marine environment were those from the soft coral A. paessleri. Alcyopterosins A-O (Figure 1) are also the first nitrate esters reported as MNPs (Palermo et al., 2000). Alcyopterosin E show mild cytotoxicity toward Hep-2 (human larynx carcinoma) cell line with $\mathrm{IC}_{50}$ of $13.5 \mu \mathrm{M}$, while alcyopterosin $\mathrm{A}, \mathrm{C}$, and $\mathrm{H}$ were cytotoxic toward HT-29 (human colon carcinoma) at $10 \mu \mathrm{g} / \mathrm{mL}$ (Palermo et al., 2000). The minor metabolites paesslerins A (Figure 1) and B show moderate cytotoxicity against human tumor cell lines (Rodriguez-Brasco et al., 2001). The paesslerane and illudalane carbocyclic skeletons could be biogenetically related by a protoilludane cation as a common precursor. On the other hand, the gorgonian coral Ainigmaptilon antarcticus possesses ainigmaptilone A (Figure 1), displaying antibiotic activity toward three sympatric Antarctic bacteria at as low as $5 \mathrm{mg} / \mathrm{mL}$ and being lethal to fouling sympatric diatoms at natural concentration $(0.275 \mathrm{mg} / \mathrm{mL}$ ) (De Marino et al., 1997a; Amsler et al., 2000).

Keikipukalides A-E (Figure 1), furanocembranoid diterpenes, along with pukalide aldehyde and the norditerpenoid ineleganolide are found in the deep-sea octocoral Plumarella delicatissima (Thomas et al., 2018). This family of diterpenes displays activity against the leishmaniasis parasite, L. donovani, from 1.9 to $12 \mu \mathrm{M}$, with no corresponding mammalian cytotoxicity below $50 \mu \mathrm{M}$. Most of these compounds contain the neurotoxic pharmacophore of lophotoxin which may be a liability for this specificity (Abramson et al., 1991). On the other hand, blue alcyonaceans present characteristic pigments contributing to the amazing colors of the benthic communities and displaying also several bioactivities (Patiño-Cano et al., 2018). The gorgonian Acanthogorgia laxa presents linderazulene and a ketolactone, both displaying good antifouling properties against a wide array of organisms. Although, the ketolactone can be produced from linderazulene by oxidation, there is some controversy regarding its possible origin as an artifact ( $\mathrm{Li}$ and Scheuer, 1984). A compound closely related to linderazulene, 8,9-dihydrolinderazulene (Figure 1), displays cytotoxicity against several tumor cell lines, like PC-3, HCT-116 and MCF-7/ADR with $\mathrm{IC}_{50}$ values of $9.46,14.49$ and $16.06 \mathrm{mg} / \mathrm{mL}$, respectively (Chen et al., 2014). Antifouling assays show that azulenoid sesquiterpenoids are also involved in the control of biofouling by marine invertebrates (Patiño-Cano et al., 2018).

Three briarane diterpenes, bathyptilone A-C (Figure 1) isolated from the sea pen, Anthoptilum grandiflorum have been screened against four cancer cell lines. Bathyptilone A is highly toxic to a pluripotent embryonal carcinoma cell line, NTera-2
(NT2), effectively killing tNT2 cells at an $\mathrm{IC}_{50}$ of $29 \mathrm{nM}$ (Thomas et al., 2019). Due to their similarity with developing neuronal cells, this cell line is considered valid for assessing neurotoxicity (Stern et al., 2014). Moreover, seven steroids from Anthomastus bathyproctus were tested against the human tumor cell lines MDA-MB-231 (breast adenocarcinoma), A-549 (lung carcinoma), and HT-29 (colon adenocarcinoma). Four of them displayed weak activity as inhibitors of cell growth, only one of them being a potent inhibitor with $\mathrm{GI}_{50}$ values of $21.2 \mu \mathrm{M}$ for MDA-MB-231, $16.5 \mu \mathrm{M}$ for A-549, and $15.3 \mu \mathrm{M}$ for HT29 (Mellado et al., 2005). Finally, two new terpenoids, shagene A (Figure 1) and B were isolated from an undescribed genus of octocoral. Shagene A has an $\mathrm{IC}_{50}$ value of $5 \mu \mathrm{M}$ on the infected macrophage stage of the leishmaniasis parasite, L. donovani, showing a 10-fold increase in activity with no cytotoxicity up to $100 \mu \mathrm{g} / \mathrm{mL}$. Shagene B showed no activity (> $20 \mu \mathrm{g} / \mathrm{mL})$ indicating the relevance of the methoxy substituent at C-8 (von Salm et al., 2014).

\section{MOLLUSCA}

Molluscs, and particularly gastropods, are a very important source of bioactive compounds, with some drugs already in the market (see Avila et al., 2008; Avila and Angulo-Preckler, 2020). Antarctic molluscs are also rich in natural products with potentially relevant bioactivities (Avila and AnguloPreckler, 2020 and references therein) (Table 1). Here, gastropod nudibranchs are among the most interesting, as for example the compounds of the slug Doris kerguelenensis, displaying a wide arsenal of NPs, including different skeletons (Avila and AnguloPreckler, 2020), among which the diterpenoids palmadorins (Figure 1) inhibit human erythroleukemia (HEL) cells at low micromolar $\mathrm{IC}_{50}$ 's and also inhibit Jak2, STAT5, and Erk1/2 activation in HEL cells, causing apoptosis at $5 \mathrm{mM}$ (Maschek et al., 2012). The structure-activity profile of the cytotoxicity of palmadorin indicates that the cis-fused labdane diterpene system may be conformable to develop potent chemotherapy tools based on the inhibition of several key enzymes implicated in the JAK/STAT pathway (Maschek et al., 2012). Several other compounds have been described in Antarctic molluscs and, for some of them, their ecological activities are described but their potential pharmacological activities remain yet to be discovered.

\section{BRYOZOA}

Bryozoans have emerged over the last decades as a source of biologically active and structurally diverse compounds, with several Antarctic species being bioactive, all of them within the Cheilostomata (Figuerola et al., 2013, 2014; Angulo-Preckler et al., 2015; Figuerola and Avila, 2019) (Table 1). The alkaloid tambjamine A is found in Bugula longissima (Lebar et al., 2007), although its bioactivity has not yet been investigated, tambjamine A was previously reported bioactive from the tropical bryozoan Sessibugula translucens (Carté and Faulkner, 1983). Several compounds are found in Aspidostoma giganteum, like aspidostomides A-H (Figure 1) and aspidazide A, but only 
aspidostomide $\mathrm{E}$ presented bioactivity, being moderately active against the 786-O renal carcinoma cell line with an $\mathrm{IC}_{50}$ of 7.8 MM (Patiño-Cano et al., 2014). Aspidostoma giganteum is found along the Magellanic and Antarctic regions, with records in Patagonia, Tierra del Fuego, Malvinas, and the South Shetland Islands. Since this bioactivity is reported in Patagonia (Argentina) specimens, it is unknown whether Antarctic specimens are also bioactive. Despite their huge potential, the scarce information available from this abundant and biodiverse phylum is an important gap, and at the same time a promising large source of pharmacologically interesting NPs.

\section{NEMERTEA}

Ribbon worms are known to be voracious predators or scavengers, provided with an eversible proboscis to capture prey and secreting a quite thick and copious mucus covering their bodies. Their mucus secretion is usually toxic to both potential predators and preys, presenting several identified compounds with potential pharmacological use, some of them being in clinical trials (Göransson et al., 2019). The mucus of the Antarctic species Parborlasia corrugatus presents cytotoxic peptide compounds and hemolytic activity toward erythrocytes, among its compounds, parbolysins are currently being investigated in detail (Göransson et al., 2019; Jacobsson et al., unpublished data) (Table 1).

\section{ECHINODERMATA}

\section{Asteroidea}

Starfish contain steroidal glycosides and saponins which are responsible for their general toxicity and antiviral activity against several human pathogenic viruses (McKee et al., 1994; Comin et al., 1999). Sulfated steroidal glycosides ubiquitously found in starfish can be classified into two major structural classes, asterosaponins and polyhydroxysteroid glycosides, displaying a wide range of biological activities, such as cytotoxic, hemolytic, ichthyotoxic, repellent, antineoplastic, antimicrobial, antifungal, antiviral, and anti-inflammatory activities (Minale et al., 1993) (Table 1). Henricia sp. presents thirty-four steroid constituents where seven asterosaponins are cytotoxic (Iorizzi et al., 1996). Antarcticoside C (Figure 1) displays the strongest cytotoxic activity with an $\mathrm{IC}_{50}$ value $<3.3 \mu \mathrm{g} / \mathrm{ml}$ (Iorizzi et al., 1996). This is one of the best examples among the echinoderms of the structural variety of polyhydroxysteroid constituents co-occurring in the same organism. Similarly, a large variety of steroid glycosides are found in an unidentified sea star of the Asteriidae family. Some of these compounds are moderately cytotoxic against human non-small-cell lung carcinoma cells (NSCLC-L16), with the sulphated steroid asterasterol $\mathrm{C}$ showing a moderate activity with IC $_{50}>30 \mu \mathrm{g} / \mathrm{ml}$ (De Marino et al., 1997b). Also, asteriidoside C, D (Figure 1), and E, were the most active steroidal sulfates with $\mathrm{IC}_{50}$ values of $19.7 \mu \mathrm{g} / \mathrm{mL}, 11.4 \mu \mathrm{g} / \mathrm{mL}$, and $18.1 \mu \mathrm{g} / \mathrm{mL}$, respectively (De Marino et al., 1998). Some more asterosaponins, the diplasteriosides A (Figure 1) and B from Diplasterias brucei show potent cytotoxic activity against different human cancer cell lines (Ivanchina et al., 2011). For HCT-116 cells, only diplasterioside A was toxic. Both compounds show moderate toxicity toward T47D cells and are most toxic against RPMI7951 cells with $\mathrm{IC}_{50} 67$ and $60 \mu \mathrm{M}$, respectively. Compounds with the ergostane skeleton are more hemolytically active than those with the cholestane one, and the presence of an additional methyl group at $\mathrm{C}_{24}$ in the side chain of diplasterioside $\mathrm{B}$ causes reduction of its cytotoxic properties compared to diplasterioside A (Ivanchina et al., 2011). These compounds have already been synthesized by using Fmoc carbonate as an orthogonal protecting group which can be removed and the product subsequently glycosylated to reduce the number of steps (Sangwan et al., 2020). Finally, 19 steroids, 13 steroidal oligoglycosides, and six polyhydroxylated steroids are found in Acodontaster conspicuous, where half of them were active against at least one Antarctic marine bacterium (De Marino et al., 1997a), suggesting that they may play an important role in deterring microbial fouling and could be further investigated for potential antibiotic and antifouling properties.

\section{Holothuroidea}

Triterpene glycosides and saponins are secondary metabolites typically found in sea cucumbers. Two trisulfated triterpene glycosides, liouvillosides A (Figure 1) and B, are found in the sea cucumber Staurocucumis liouvillei (Maier et al., 2001). Both glycosides were found to be virucidal against herpes simplex virus type $1(\mathrm{HSV}-1)$ at concentrations below $10 \mu \mathrm{g} / \mathrm{ml}$, while little or no cytotoxicity was detected within $8 \mathrm{~h}$ of cell exposure (Maier et al., 2001). Other liouvillosides also found in S. liouvillei and $S$. turqueti have not been yet tested for bioactivity (Antonov et al., 2008, 2011; Silchenko et al., 2013). Similarly, achlioniceosides from the elasipod Achlionice violaecuspidata are not studied yet for their bioactivity (Antonov et al., 2009).

\section{Ophiuroidea}

Also saponins and steroids are responsible here for the antiviral activity against several human pathogenic viruses (McKee et al., 1994; Comin et al., 1999). Three steroids from the brittle star Ophiosparte gigas are characterized by the hydroxylation at C-3a and C-21 and the cis- Ah3 ring fusion. One of them is extremely cytotoxic even at the lowest concentration of $0.12 \mu \mathrm{g} / \mathrm{ml}$, whereas the other two are active against HIV-1 with $\mathrm{EC}_{50}$ values of ca. 50-100 $\mathrm{g} / \mathrm{ml}$ (D’Auria et al., 1993).

\section{TUNICATA}

Antarctic ascidians display high levels of endemism, reaching 25-51\% of endemic species (Primo and Vázquez, 2009). While most ascidian metabolites are amino acid derived (Wang and Namikoshi, 2007), ascidians of the genus Aplidium are noted for possessing terpene derivatives (Zubía et al., 2005). Examples of NPs from Antarctic ascidians include palmerolide A, ecdysteroids, meridianins, aplicyanins, and rossinones (Figure 1; Table 1) (Diyabalanage et al., 2006; Miyata et al., 2007; Seldes et al., 2007; Reyes et al., 2008; Appleton et al., 2009; NúñezPons et al., 2010, 2012, 2015; Núñez-Pons and Avila, 2015). 
However, it is often unclear whether tunicates are the true producers of the molecules or whether associated microbes may play a role in their synthesis and chemical ecology (NúñezPons et al., 2012). Aplidium species are the source of numerous nitrogen-containing metabolites belonging to unprecedented structural families of NPs (Zubía et al., 2005). Six bromoindole derivatives, aplicyanins A-F (Figure 1) from A. cyaneum are cytotoxic against human tumor cell lines A-549, HT-29, and MDA-MB-231, and show antimitotic properties (for aplicyanins $\mathrm{B}, \mathrm{D}, \mathrm{E}$, and $\mathrm{F}$ ), thus suggesting a key role for the acetyl group at N-16 in their biological activity (Reyes et al., 2008). These compounds are reduced forms of the structurally related meridianins isolated from $A$. meridianum and can therefore be considered their biogenetic precursors. Meridianins are a family of indole alkaloids consisting of an indole framework linked to an aminopyrimidine ring. Meridianins A-E (Figure 1) from A. meridianum present cytotoxicity toward LMM3 (murine mammarian adenocarcinoma cell line) at $\mathrm{IC}_{50}$ values of $11.4 \mu \mathrm{M}$ for meridianin $\mathrm{B}, 9.3 \mu \mathrm{M}$ for meridianin $\mathrm{C}, 33.9 \mu \mathrm{M}$ for meridianin D, and 11.1 $\mu \mathrm{M}$ for meridianin $\mathrm{E}$ (Franco et al., 1998). Aiming to find possible molecular targets for a set of MNPs, it was reported that some meridianins can interact with proteins involved in neurodegenerative diseases (Llorach-Parés et al., 2017, 2018). In fact, meridianins are found particularly interesting as potential therapeutic agents against Alzheimer disease (AD) (Llorach-Parés et al., 2017) and computational chemistry and in vitro assays have recently shown promising results (Llorach-Parés et al., 2020). Currently there is no treatment that cures or even slows $\mathrm{AD}$ progression, and therefore, there is a need for new and improved therapeutic molecules for these diseases, as their impact is expected to increase due to the shift in world demography. Although we are far from having solutions, potential benefits of a treatment for AD are huge and would clearly result in improving patients health and reducing societal costs.

Furthermore, rossinones A (Figure 1) and B are biologically active meroterpene derivatives from Aplidium species (Appleton et al., 2009; Núñez-Pons et al., 2012). Rossinones possess antiinflammatory, antiviral, and antiproliferative activities (Appleton et al., 2009). In an in vitro anti-inflammatory assay with activated human peripheral blood neutrophils, rossinones inhibited superoxide production when either $\mathrm{N}$-formyl-methionyl-leucylphenylalanine (fMLP) ( $\mathrm{IC}_{50} 1.9$ and $2.5 \mu \mathrm{M}$, respectively) or phorbol myristate acetate (PMA) ( $\mathrm{IC}_{50} 0.8$ and $0.7 \mu \mathrm{M}$, respectively) were used to activate the respiratory burst (Tan and Berridge, 2000). Also a selective antiviral activity toward DNAvirus HSV-1, versus the RNAvirus PV-1 is described for both compounds, with antiviral activity at $2 \mu \mathrm{g} / \mathrm{disk}$. Both compounds also present antimicrobial activity against the Gram + bacterium B. subtilis and the fungi Trichophyton mentagrophytes at $60 \mu \mathrm{g} /$ disk (Appleton et al., 2009).

An enamide-bearing polyketide, the palmerolide A (Figure 1) from the common tunicate Synoicum adareanum targets melanoma (UACC-62, $\mathrm{LC}_{50}=18 \mathrm{nM}$ ), colon cancer cell line (HCC-2998, $\left.\mathrm{LC}_{50}=6.5 \mu \mathrm{M}\right)$ and renal cancer cell lines (RXF 393, $\left.\mathrm{LC}_{50}=6.5 \mu \mathrm{M}\right)$ (Diyabalanage et al., 2006; Riesenfeld et al., 2008; Murray et al., 2020). Palmerolide A is stable for extended time periods and does not readily yield a single hydrolysis product. Later studies isolated palmerolides A $(0.002 \mu \mathrm{M}), \mathrm{D}(0.025 \mu \mathrm{M})$, and $\mathrm{G}(0.007 \mu \mathrm{M})$. All palmerolides containing the $\mathrm{C}-2^{\prime} / \mathrm{C}-3^{\prime}$ olefin are very potent $\mathrm{V}$-ATPase inhibitors, whereas palmerolide F $(0.063 \mu \mathrm{M})$ which lacks the above mentioned olefin is significantly less potent (Noguez et al., 2011). Palmerolide E, lacking the entire carboxamide functionality, appears to retain inhibitory activity $\left(\mathrm{IC}_{50} 5 \mu \mathrm{M}\right)$ toward melanoma while losing effectiveness against $\mathrm{V}$-ATPase $\left(\mathrm{IC}_{50}>10 \mu \mathrm{M}\right)$. This suggests that different parts of the side chain are responsible for the activities exhibited against UACC-62 and V-ATPase (Noguez et al., 2011). Most of these palmerolides are potent V-ATPase inhibitors and have sub-micromolar activity against melanoma but palmerolides are less neurotoxic than other V-ATPase inhibitors. Palmerolide $\mathrm{C}$ is a congeneric macrolide of palmerolide A exhibiting similar bioactivity toward the UACC-62 human melanoma cell line ( $\mathrm{IC}_{50}=110 \mathrm{nM}$ ) (Sayyad et al., 2020). $S$. adareanum also presents the known ecdysteroid diaulusterol $\mathrm{B}$, as well as five more ecdysteroids, hyousterones A-D (Miyata et al., 2007). These ecdysteroids were evaluated for solid tumor selective cytotoxicity using colon (colon 38, HCT-116), lung (H-125M), leukemia (L1210, CCRF-CEM), and normal (CFUGM) cell lines. Abeohyousterone (Figure 1) possesses moderate cytotoxicity toward several cancer cell lines while hyousterones A and C, bearing the 14R-hydroxy group, were weakly cytotoxic (Miyata et al., 2007).

Finally, 21 fatty acids and some sterols are found in the pelagic Salpa thompsoni, with the total fatty acids fraction being strongly hemolytic, and the polyunsaturated acids DHA: $6 \omega 3$ and EPA: $5 \omega 3$ as the most potent compounds (Mimura et al., 1986). Slight changes in the position and the geometry of the double bond seem to affect the potency of hemolytic activity of these compounds.

\section{MANAGING BIODISCOVERY IN ANTARCTICA}

Studying and using bioactive MNPs while conserving biodiversity is crucial, and further synthesizing the useful bioactive compounds in the laboratory is a must. The tenth Conference of the Parties (CoP10) to the Convention on Biological Diversity (CBD) held in Nagoya (2010) led to the adoption of a global Strategic Plan for biodiversity 2011-2020, the Nagoya Protocol on Access to Genetic Resources, and the Fair and Equitable Sharing of Benefits Arising from their Utilization (ABS Protocol), as well as a strategy to mobilize resources for global biodiversity. European policies defend that all these protocols shall indeed include marine biotechnology. In fact, the new resources obtained from marine research and the so-called blue biotechnologies are currently considered an emerging sector, with a promising growth of $10 \%$ per year and a global market of $€ 2.4$ billion estimated in $2008^{4}$. Biodiversity, and all the services it provides, has a significant economic value that is seldom

\footnotetext{
${ }^{4}$ https://ec.europa.eu/maritimeaffairs/sites/maritimeaffairs/files/docs/ publications/blue-growth_en.pdf
} 
captured in markets, as recognized by the European Union, 2020 biodiversity target. In the short term, economic impacts have to be considered in terms of research activities and involved SMEs. In a medium to long term period, commercialization of bioactive products discovered would generate economic impacts in anticancer, against neurodegenerative diseases, antimicrobial, antiviral, antifungal, antiparasitic, enzymes (protease inhibitors, etc.), antioxidant (skin protection), and potentially many other applications. Antarctic MNPs may be an important source of new drugs for the future, and therefore should be explored according to the mentioned regulations. Furthermore, Antarctic studies are regulated by the Antarctic Treaty system (ATS) and the Madrid Protocol, establishing what we can and what we cannot do for research there. Sustainable Development Goals (SDGs), moreover, have to be considered here too. In fact, all regulations try to protect biodiversity (and thus, chemodiversity) while carrying out biodiscovery research.

\section{CONCLUDING REMARKS}

In this minireview we showcase the diverse bioactivities described in Antarctic MNPs, their original chemical structures, and the huge potential they possess. A total of 37 species have been reported, including 15 Porifera, eight Cnidaria, one Mollusca, one Bryozoa, one Nemertea, six Echinodermata, and five Tunicata. The amazing biodiversity the Antarctic benthos holds, as well as their inherent chemodiversity, must be protected by all means to avoid their disappearance according to the established regulations. In fact, the current popularity of MNPs in cosmetic, food, pharmaceutical industries, etc. is rising concerns about sustainability all over the planet. If we aim to use this chemodiversity for human benefits we must keep the biological diversity, solving the supply problem, using

\section{REFERENCES}

Abida, H., Ruchaud, S., Rios, L., Humeau, A., Probert, I., De Vargas, C., et al. (2013). Bioprospecting marine plankton. Mar. Drugs 11, 4594-4611. doi: 10. 3390/md11114594

Abramson, S. N., Trischman, J. A., Tapiolas, D. M., Harold, E. E., Fenical, W., and Taylor, P. (1991). Structure/activity and molecular modeling studies of the Lophotoxin family of irreversible nicotinic receptor antagonists. J. Med. Chem. 34, 1798-1804. doi: 10.1021/jm00110a007

Amsler, C. D., Moeller, C. B., McClintock, J. B., Iken, K. B., and Baker, B. J. (2000). Chemical defenses against diatom fouling in Antarctic marine sponges. Biofouling 16, 29-45. doi: 10.1080/08927010009378428

Angulo-Preckler, C., Cid, C., Oliva, F., and Avila, C. (2015). Antifouling activity in some benthic Antarctic invertebrates by in situ experiments at deception Island, Antarctica. Mar. Environ. Res. 105, 30-38. doi: 10.1016/j.marenvres.2015.02. 001

Angulo-Preckler, C., San Miguel, O., García-Aljaro, C., and Avila, C. (2017). Antibacterial defenses and palatability of some shallow-water Antarctic sponges. Hydrobiologia 806, 123-138. doi: 10.1007/s10750-017-3346-5

Ankisetty, S., Amsler, C. D., McClintock, J. B., and Baker, B. J. (2004). Further membranolide diterpenes from the antarctic sponge Dendrilla membranosa. J. Nat. Prod. 67, 1172-1174. doi: 10.1021/np0340551

Antonov, A. S., Avilov, S. A., Kalinovsky, A. I., Anastyuk, S. D., Dmitrenok, P. S., Evtushenko, E. V., et al. (2008). Triterpene glycosides from antarctic synthesis, targeting biosynthetic gene clusters (BGCs), and using all the omics, informatic tools and databases currently available to move forward without damaging the ecosystems. When MNPs are obtained by cultures these concerns diminish considerably. The current research gaps and the potential future developments have been indicated here, and even if the interest on bioprospecting MNPs is exponentially growing, still new techniques and approaches have to improve to overcome the common bottlenecks in MNPs pipelines, speeding the process and decreasing research costs to fully exploit the benefits of biodiscovery in Antarctic MNPs in a near future in a sustainable way.

\section{AUTHOR CONTRIBUTIONS}

CA: idea and conceptualization. CA and CA-P: literature review, writing, and editing. Both authors contributed to the article and approved the submitted version.

\section{FUNDING}

This work was developed within the frames of the BLUEBIO and CHALLENGE research projects (CTM2016-78901 and PID2019107979/ANT, Spanish government) and with support from a 2017SGR1120 grant of the Catalan government. CA-P was supported by the Ramon Areces Foundation.

\section{ACKNOWLEDGMENTS}

Thanks are due to all the members of the BLUEBIO and CHALLENGE research projects for their support. This is an AntICON (SCAR) contribution. sea cucumbers. 1. Structure of liouvillosides A1, A2, A3, B1, and B2 from the sea cucumber Staurocucumis liouvillei: new procedure for separation of highly polar glycoside fractions and taxonomic revision. J. Nat. Prod. 71, 1677-1685. doi: 10.1021/np800173c

Antonov, A. S., Avilov, S. A., Kalinovsky, A. I., Anastyuk, S. D., Dmitrenok, P. S., Kalinin, V. I., et al. (2009). Triterpene glycosides from Antarctic sea cucumbers. 2. Structure of Achlioniceosides A1, A2, and A3 from the sea cucumber Achlionice violaecuspidata (= Rhipidothuria racowitzai). J. Nat. Prod. 72, 33-38. doi: 10.1021/np800469v

Antonov, A. S., Avilov, S. A., Kalinovsky, A. I., Dmitrenok, P. S., Kalinin, V. I., Taboada, S., et al. (2011). Triterpene glycosides from Antarctic sea cucumbers III. Structures of liouvillosides A4 and A5, two minor disulphated tetraosides containing 3-O-methylquinovose as terminal monosaccharide units from the sea cucumber Staurocucumis liouvillei (Vaney). Nat. Prod. Res. 25, 1324-1333. doi: 10.1080/14786419.2010.531017

Appleton, D. R., Chuen, C. S., Berridge, M. V., Webb, V. L., and Copp, B. R. (2009). Rossinones A and B, biologically active meroterpenoids from the Antarctic ascidian, Aplidium species. J. Org. Chem. 74, 9195-9198. doi: 10.1021/ jo901846j

Arrieta, J. M., Arnaud-Haond, S., and Duarte, C. M. (2010). What lies underneath: conserving the oceans' genetic resources. Proc. Natl. Acad. Sci. U.S.A. 107, 18318-18324. doi: 10.1073/pnas.0911897107

Avila, C. (2016a). Biological and chemical diversity in Antarctica: from new species to new natural products. Biodiversity $17,1-7$. 
Avila, C. (2016b). Ecological and pharmacological activities of Antarctic marine natural products. Planta Med. 82, 767-774. doi: 10.1055/s-0042- 105652

Avila, C., and Angulo-Preckler, C. (2020). Bioactive compounds from marine Heterobranchs. Mar. Drugs 18:657. doi: 10.3390/md18120657

Avila, C., Taboada, S., and Núñez-Pons, L. (2008). Antarctic marine chemical ecology: what's next? Mar. Ecol. 29, 1-71. doi: 10.1111/j.1439-0485.20 07.00215.x

Beattie, A. J., Hay, M., Magnusson, B., de Nys, R., Smeathers, J., and Vincent, J. F. (2011). Ecology and bioprospecting. Austral Ecol. 36, 341-356. doi: 10.1111/j. 1442-9993.2010.02170.x

Bérdy, J. (2012). Thoughts and facts about antibiotics: where we are now and where we are heading. J. Antibiot. 65, 385-395. doi: 10.1038/ja.2012.27

Bory, A., Shilling, A., Allen, J. L., Azhari, A., Roth, A., Shaw, L., et al. (2020). Bioactivity of spongian diterpenoid scaffolds from the Antarctic sponge Dendrilla antarctica. Mar. Drugs 18, 327. doi: 10.3390/md18060327

Botić, T., Defant, A., Zanini, P., Žužek, M. C., Frangež, R., Janussen, D., et al. (2017). Discorhabdin alkaloids from Antarctic Latrunculia spp. sponges as a new class of cholinesterase inhibitors. Eur. J. Med. Chem. 136, 294-304. doi: 10.1016/j.ejmech.2017.05.019

Buenz, E. J., Verpoorte, R., and Bauer, B. A. (2018). The ethnopharmacologic contribution to bioprospecting natural products. Annu. Rev. Pharmacol. Toxicol. 58, 509-530. doi: 10.1146/annurev-pharmtox-010617-052703

Carroll, A. R., Copp, B. R., Davis, R. A., Keyzers, R. A., and Prinsep, M. R. (2020). Marine natural products. Nat. Prod. Rep. 37, 175-223.

Carté, B., and Faulkner, D. J. (1983). Defensive metabolites from three nembrothid nudibranchs. J. Org. Chem. 48, 2314-2318. doi: 10.1021/jo00162a003

Chen, M., Han, L., Wang, Y., Zhang, X. L., and Wang, C. Y. (2014). A new sesquiterpene from the Hainan gorgonian Menella kanisa Grassoff. Nat. Prod. Res. 28, 1147-1151. doi: 10.1080/14786419.2014.918122

Ciaglia, E., Malfitano, A. M., Laezza, C., Fontana, A., Nuzzo, G., Cutignano, A., et al. (2017). Immuno-modulatory and anti-inflammatory effects of Dihydrogracilin A, a terpene derived from the marine sponge Dendrilla membranosa. Int. J. Mol. Sci. 18:1643. doi: 10.3390/ijms18081643

Comin, M. J., Maier, M. S., Roccatagliata, A. J., Pujol, C. A., and Damonte, E. B. (1999). Evaluation of the antiviral activity of natural sulfated polyhydroxysteroids and their synthetic derivatives and analogs. Steroids 64 , 335-340. doi: 10.1016/s0039-128x(99)00016-1

Cushnie, T. P., Cushnie, B., Echeverría, J., Fowsantear, W., Thammawat, S., Dodgson, J. L., et al. (2020). Bioprospecting for antibacterial drugs: a multidisciplinary perspective on natural product source material, bioassay selection and avoidable pitfalls. Pharm. Res. 37:125. doi: 10.1007/s11095-02002849-1

D’Ambrosio, M., Guerriero, A., Chiasera, G., Pietra, F., and Tatò, M. (1996). Epinardins A-D, new pyrroloiminoquinone alkaloids of undetermined deepwater green demosponges from pre-Antarctic Indian ocean. Tetrahedron 52, 8899-8906. doi: 10.1016/0040-4020(96)00438-3

D’Auria, M. V., Paloma, L. G., Minale, L., Riccio, R., Zampella, A., and Morbidoni, M. (1993). Isolation and structure characterization of two novel bioactive sulphated polyhydroxysteroids from the Antarctic ophiuroid Ophioderma longicaudum. Nat. Prod. Let. 3, 197-201. doi: 10.1080/10575639308043863

De Marino, S., Iorizzi, M., Palagiano, E., Zollo, F., and Roussakis, C. (1998). Starfish saponins. 55.1 Isolation, structure elucidation, and biological activity of the steroid oligoglycosides from an Antarctic starfish of the family Asteriidae. J. Nat. Prod. 61, 1319-1327. doi: 10.1021/np970500e

De Marino, S., Iorizzi, M., Zollo, F., Minale, L., Amsler, C. D., Baker, B. J., et al. (1997a). Isolation, structure elucidation, and biological activity of the steroid oligoglycosides and polyhydroxysteroids from the Antarctic starfish Acodontaster conspicuus. J. Nat. Prod. 60, 959-966. doi: 10.1021/np9700578

De Marino, S., Palagiano, E., Zollo, F., Minale, L., and Iorizzi, M. (1997b). A novel sulphated steroid with a 7-membered 5-oxalactone B-ring from an Antarctic starfish of the family Asteriidae. Tetrahedron 53, 8625-8628. doi: 10.1016/ s0040-4020(97)00531-0

Diyabalanage, T., Amsler, C. D., McClintock, J. B., and Baker, B. J. (2006). Palmerolide A, a cytotoxic macrolide from the Antarctic tunicate Synoicum adareanum. J. Am. Chem. Soc. 128, 5630-5631. doi: 10.1021/ja0588508

Eisner, T. (1990). Prospecting for nature's chemical riches. Chemoecology 1, 38-40. doi: $10.1007 / \mathrm{bf} 01240585$
Fan, X., Bai, L., Zhu, L., Yang, L., and Zhang, X. (2014). Marine algae-derived bioactive peptides for human nutrition and health. J. Agric. Food Chem. 62, 9211-9222. doi: 10.1021/jf502420h

Figuerola, B., and Avila, C. (2019). The phylum bryozoa as a promising source of anticancer drugs. Mar. Drugs 17:477. doi: 10.3390/md17080477

Figuerola, B., Núñez-Pons, L., Moles, J., and Avila, C. (2013). Feeding repellence in Antarctic bryozoans. Naturwiss 100, 1069-1081. doi: 10.1007/s00114-013$1112-8$

Figuerola, B., Sala-Comorera, L., Angulo-Preckler, C., Vázquez, J., Montes, M. J., García-Aljaro, C., et al. (2014). Antimicrobial activity of Antarctic bryozoans: an ecological perspective with potential for clinical applications. Mar. Environ. Res. 101, 52-59. doi: 10.1016/j.marenvres.2014.09.001

Ford, J., and Capon, R. J. (2000). Discorhabdin R: a new antibacterial pyrroloiminoquinone from two latrunculiid marine sponges, Latrunculia sp. and Negombata sp. J. Nat. Prod. 63, 1527-1528. doi: 10.1021/np000220q

Franco, L. H., Joffé, E. B., Puricelli, L., Tatian, M., Seldes, A. M., and Palermo, J. A. (1998). Indole alkaloids from the tunicate Aplidium meridianum. J. Nat. Prod. $61,1130-1132$.

Gavagnin, M., Mollo, E., Castelluccio, F., Crispino, A., and Cimino, G. (2003). Sesquiterpene metabolites of the Antarctic gorgonian Dasystenella acanthina. J. Nat. Prod. 66, 1517-1519. doi: 10.1021/np03 0201r

Gerwick, W. H., and Fenner, A. M. (2013). Drug discovery from marine microbes. Microb. Ecol. 65, 800-806. doi: 10.1007/s00248-012-0169-9

Gerwick, W. H., and Moore, B. S. (2012). Lessons from the past and charting the future of marine natural products drug discovery and chemical biology. Chem. Biol. 19, 85-98. doi: 10.1016/j.chembiol.2011.12.014

Giordano, D., Costantini, M., Coppola, D., Lauritano, C., Núñez Pons, L., Ruocco, N., et al. (2018). Biotechnological applications of bioactive peptides from marine sources. Adv. Microb. Physiol. 73, 171-220. doi: 10.1016/bs.ampbs.2018. 05.002

Göransson, U., Jacobsson, E., Strand, M., and Andersson, H. S. (2019). The toxins of nemertean worms. Toxins 11:120. doi: 10.3390/toxins11020120

Griffiths, H. J. (2010). Antarctic marine biodiversity-what do we know about the distribution of life in the Southern Ocean? PLoS One 5:e11683. doi: 10.1371/ journal.pone. 0011683

Gupta, P. L., Rajput, M., Oza, T., Trivedi, U., and Sanghvi, G. (2019). Eminence of microbial products in cosmetic industry. Nat. Prod. Bioprosp. 9, 267-278. doi: 10.1007/s13659-019-0215-0

Höller, U., Wright, A. D., Matthee, G. F., Konig, G. M., Draeger, S., HansJürgen, A., et al. (2000). Fungi from marine sponges: diversity, biological activity and secondary metabolites. Mycol. Res. 104, 1354-1365. doi: 10.1017/ s0953756200003117

Hu, G. P., Yuan, J., Sun, L., She, Z. G., Wu, J. H., Lan, X. J., et al. (2011). Statistical research on marine natural products based on data obtained between 1985 and 2008. Mar. Drugs 9, 514-525. doi: 10.3390/md9040514

Iken, K. B., and Baker, B. J. (2003). Ainigmaptilones, sesquiterpenes from the Antarctic gorgonian coral Ainigmaptilon antarcticus. J. Nat. Prod. 66, 888-890. doi: $10.1021 / \mathrm{np} 030051 \mathrm{k}$

Imhoff, J. F., Labes, A., and Wiese, J. (2011). Bio-mining the microbial treasures of the ocean: new natural products. Biotechnol. Adv. 29, 468-482. doi: 10.1016/j. biotechadv.2011.03.001

Iorizzi, M., De Marino, S., Minale, L., Zollo, F., Le Bert, V., and Roussakis, C. (1996). Investigation of the polar steroids from an Antarctic starfish of the family Echinasteridae: isolation of twenty seven polyhydroxysteroids and steroidal oligoglycosides, structures and biological activities. Tetrahedron 52, 10997-11012. doi: 10.1016/0040-4020(96)00618-7

Ivanchina, N. V., Malyarenko, T. V., Kicha, A. A., Kalinovsky, A. I., Dmitrenok, P. S., and Ermakova, S. P. (2011). Structures and cytotoxic activities of two new asterosaponins from the Antarctic starfish Diplasterias brucei. Russ. J. Bioorg. Chem. 37, 499-506. doi: 10.1134/s1068162011 030083

Jabour-Green, J., and Nicol, D. (2003). Bioprospecting in areas outside national jurisdiction: Antarctica and the Southern Ocean. Melb. J. Int. L. 4, 76-111.

Jaspars, M., De Pascale, D., Andersen, J. H., Reyes, F., Crawford, A. D., and Ianora, A. (2016). The marine biodiscovery pipeline and ocean medicines of tomorrow. J. Mar. Biol. Assoc. U.K. 96, 151-158. doi: 10.1017/s0025315415002106 
Jayatilake, G. S., Baker, B., and McClintock, J. (1995). Isolation and identification of a stilbene derivative from the Antarctic sponge Kirkpatrickia variolosa. J. Nat. Prod. 58, 1958-1960. doi: 10.1021/np50126a028

Jayatilake, G. S., Baker, B. J., and McClintock, J. B. (1997). Rhapsamine, a cytotoxin from the Antarctic sponge Leucetta leptorhapsis. Tetrahedron Let. 38, 75077510. doi: 10.1016/s0040-4039(97)01802-9

Kayser, O., Kiderlen, A. F., and Croft, S. L. (2003). Natural products as antiparasitic drugs. Parasitology Res. 90, 55-62.

Kim, S.-K., and Wijesekara, I. (2010). Development and biological activities of marine-derived bioactive peptides: a review. J. Funct. Food 2, 1-9. doi: 10.1016/ j.jff.2010.01.003

Knestrick, M. A., Wilson, N. G., Roth, A., Adams, J., and Baker, B. (2019). Friomaramide, a highly modified linear hexapeptide from an Antarctic sponge, inhibits Plasmodium falciparum liver-stage development. J. Nat. Prod. 82, 2354-2358. doi: 10.1021/acs.jnatprod.9b00362

Leal, M. C., Puga, J., Serôdio, J., Gomes, N. C. M., and Calado, R. (2012). Trends in the discovery of new marine natural products from invertebrates over the last two decades-where and what are we bioprospecting? PLoS One 7:e30580. doi: 10.1371/journal.pone.0030580

Lebar, M. D., Heimbegner, J. L., and Baker, B. J. (2007). Cold-water marine natural products. Nat. Prod. Rep. 24, 774-797. doi: 10.1039/b516240h

Li, F., Janussen, D., Peifer, C., Pérez-Victoria, I., and Tasdemir, D. (2018). Targeted isolation of tsitsikammamines from the Antarctic deep-sea sponge Latrunculia biformis by molecular networking and anticancer activity. Mar. Drugs 16, 268. doi: $10.3390 / \mathrm{md} 16080268$

Li, F., Janussen, D., and Tasdemir, D. (2020a). New discorhabdin B dimers with anticancer activity from the Antarctic deep-sea sponge Latrunculia biformis. Mar. Drugs 18:107. doi: 10.3390/md18020107

Li, F., Pandey, P., Janussen, D., Chittiboyina, A. G., Ferreira, D., and Tasdemir, D. (2020b). Tridiscorhabdin and didiscorhabdin, the first discorhabdin oligomers linked with a direct C-N bridge from the sponge Latrunculia biformis collected from the deep sea in Antarctica. J. Nat. Prod. 83, 706-713. doi: 10.1021/acs. jnatprod.0c00023

Li, F., Peifer, C., Janussen, D., and Tasdemir, D. (2019). New discorhabdin alkaloids from the Antarctic deep-sea sponge Latrunculia biformis. Mar. Drugs 17:439. doi: $10.3390 / \mathrm{md} 17080439$

Li, M. K., and Scheuer, P. J. (1984). A guaianolide pigment from a deep sea gorgonian. Tetrahedron Lett. 25, 2109-2110. doi: 10.1016/s0040-4039(01) 81173-4

Llorach-Parés, L., Nonell-Canals, A., Avila, C., and Sanchez-Martinez, M. (2018). Kororamides, Convolutamines, and Indole derivatives as possible tau and dualspecificity Kinase inhibitors for Alzheimer's disease: a computational study. Mar. Drugs 16:386. doi: 10.3390/md16100386

Llorach-Parés, L., Nonell-Canals, A., Sánchez-Martínez, M., and Avila, C. (2017). Computer-aided drug design applied to marine drug discovery: meridianins as Alzheimer's disease therapeutic agents. Mar. Drugs 15, 366-395. doi: 10.3390/ md15120366

Llorach-Parés, L., Rodriguez-Urgelles, E., Nonell-Canals, A., Alberch, J., Avila, C., Sanchez-Martinez, M., et al. (2020). Meridianins and lignarenone B as potential GSK3 $\beta$ inhibitors and inductors of structural neuronal plasticity. Biomolecules 10:639. doi: 10.3390/biom10040639

Ma, W. S., Mutka, T., Vesley, B., Amsler, M. O., McClintock, J., Amsler, C., et al. (2009). Norselic acids A-E, highly oxidized anti-infective steroids that deter mesograzer predation, from the Antarctic sponge Crella sp. J. Nat. Prod. 72, 1842-1846. doi: $10.1021 / \mathrm{np} 900382 \mathrm{x}$

Maier, M. S., Roccatagliata, A. J., Kuriss, A., Chludil, H., Seldes, A. M., Pujol, C. A., et al. (2001). Two new cytotoxic and virucidal trisulfated triterpene glycosides from the Antarctic sea cucumber Staurocucumis liouvillei. J. Nat. Prod. 64, 732-736. doi: $10.1021 / \mathrm{np} 000584 \mathrm{i}$

Martins, A., Vieira, H., Gaspar, H., and Santos, S. (2014). Marketed marine natural products in the pharmaceutical and cosmeceutical industries: tips for success. Mar. Drugs 12, 1066-1101. doi: 10.3390/md12021066

Maschek, J. A., Mevers, E., Diyabalanage, T., Chen, L., Ren, Y., McClintock, J. B., et al. (2012). Palmadorin chemodiversity from the Antarctic nudibranch Austrodoris kerguelenensis and inhibition of Jak2/STAT5dependent HEL leukemia cells. Tetrahedron 68, 9095-9104. doi: 10.1016/j.tet.2012.08.045
Mayer, A. M., Glaser, K. B., Cuevas, C., Jacobs, R. S., Kem, W., Little, R. D., et al. (2010). The odyssey of marine pharmaceuticals: a current pipeline perspective. Trends Pharmacol. Sci. 31, 255-265. doi: 10.1016/j.tips.2010.02.005

Mayer, A. M., Rodriguez, A. D., Taglialatela-Scafati, O., and Fusetani, N. (2013). Marine pharmacology in 2009-2011: marine compounds with antibacterial, Antidiabetic, antifungal, anti-inflammatory, antiprotozoal, antituberculosis, and antiviral activities; affecting the immune and nervous systems, and other miscellaneous mechanisms of action. Mar. Drugs 11, 2510-2573. doi: 10.3390/ md11072510

Mazarrasa, I., Olsen, Y. S., Mayol, E., Marbà, N., and Duarte, C. M. (2014). Global unbalance in seaweed production, research effort and biotechnology markets. Biotechnol. Adv. 32, 1028-1036. doi: 10.1016/j.biotechadv.2014.05.002

McClintock, J. B., Amsler, C. D., Baker, B. J., and Van Soest, R. W. M. (2005). Ecology of Antarctic marine sponges: an overview. Integr. Comp. Biol. 45, 359-368. doi: $10.1093 / \mathrm{icb} / 45.2 .359$

McKee, T. C., Cardellina, J. H., Riccio, R., D’Auria, M. V., Iorizzi, M., Minale, L., et al. (1994). HIV-inhibitory natural products. 11. Comparative studies of sulfated sterols from marine invertebrates. J. Med. Chem. 37, 793-797. doi: $10.1021 /$ jm00032a012

Mellado, G. G., Zubía, E., Ortega, M. J., and López-González, P. J. (2005). Steroids from the Antarctic octocoral Anthomastus bathyproctus. J. Nat. Prod. 68, 11111115. doi: $10.1021 / \mathrm{np} 050080 \mathrm{q}$

Mellado, G. G., Zubìa, E., Ortega, M. J., and López-González, P. J. (2004). New polyoxygenated steroids from the Antarctic octocoral Dasystenella acanthina. Steroids 69, 291-299. doi: 10.1016/j.steroids.2004.02.005

Mimura, T., Okabe, M., Satake, M., Nakanishi, T., Inada, A., Fujimoto, Y., et al. (1986). Fatty acids and sterols of the tunicate, Salpa thompsoni, from the Antarctic Ocean: chemical composition and hemolytic activity. Chem. Pharmaceut. Bull. 34, 4562-4568. doi: 10.1248/cpb.34.4562

Minale, L., Riccio, R., and Zollo, F. (1993). Steroidal oligoglycosides and polyhydroxysteroids from Echinoderms. Prog. Chem. Org. Nat. Prod. 62, 308.

Miyata, Y., Diyabalanage, T., Amsler, C. D., McClintock, J. B., Valeriote, F. A., and Baker, B. J. (2007). Ecdysteroids from the Antarctic tunicate Synoicum adareanum. J. Nat. Prod. 70, 1859-1864. doi: 10.1021/np0702739

Moles, J., Torrent, A. M., Alcaraz, M. J., Ruhí, R., and Avila, C. (2014). Antiinflammatory activity in selected Antarctic benthic organisms. Front. Mar. Sci. 1:24. doi: 10.3389/fmars.2014.00024

Molinski, T. F., and Faulkner, D. J. (1987). Metabolites of the Antarctic sponge Dendrilla membranosa. J. Org. Chem. 1987, 296-298. doi: 10.1021/jo00378a031

Molinski, T. F., and Faulkner, D. J. (1988). An antibacterial pigment from the sponge Dendrilla membranosa. Tetrahedron Lett. 29, 2137-2138. doi: 10.1016/ s0040-4039(00)86692-7

Moon, B., Baker, B. J., and McClintock, J. B. (1998). Purine and nucleoside metabolites from the Antarctic sponge Isodictya erinacea. J. Nat. Prod. 61, 116-118. doi: 10.1021/np970358h

Moon, B., Park, Y. C., McClintock, J. B., and Baker, B. (2000). Structure and bioactivity of erebusinone, a pigment from the Antarctic sponge Isodictya erinacea. Tetrahedron 56, 9057-9062. doi: 10.1016/s0040-4020(00)00760-2

Murray, A. E., Avalon, N. E., Bishop, L., Davenport, K. W., Delage, E., Dichosa, A. E. K., et al. (2020). Uncovering the core microbiome and distributions of palmerolide in Synoicum adareanum across the Anvers Island archipelago, Antarctica. Mar. Drugs 18:298. doi: 10.1101/2020.02.20.958975

Newman, D. J., and Cragg, G. M. (2012). Natural products as sources of new drugs over the 30 years from 1981 to 2010. J. Nat. Prod. 75, 311-335. doi: $10.1021 / \mathrm{np} 200906 \mathrm{~s}$

Newman, D. J., and Cragg, G. M. (2016). Natural products as sources of new drugs from 1981 to 2014. J. Nat. Prod. 79, 629-661. doi: 10.1021/acs.jnatprod.5b01055

Nishimura, S., Arita, Y., Honda, M., Iwamoto, K., Matsuyama, A., Shirai, A., et al. (2010). Marine antifungal theonellamides target 3beta-hydroxysterol to activate Rho1 signaling. Nat. Chem. Biol. 6, 519-526. doi: 10.1038/nchembio.387

Noguez, J. H., Diyabalanage, T. K., Miyata, Y., Xie, X. S., Valeriote, F. A., Amsler, C. D., et al. (2011). Palmerolide macrolides from the Antarctic tunicate Synoicum adareanum. Bioorgan. Med. Chem. 19, 6608-6614. doi: 10.1016/j. bmc.2011.06.004

Núñez-Pons, L., and Avila, C. (2015). Natural products mediating ecological interactions in Antarctic ecosystems: A mini-review of the known molecules. Nat. Prod. Rep. 32, 1114-1130. doi: 10.1039/c4np00150h 
Núñez-Pons, L., Carbone, M., Vázquez, J., Rodríguez, J., Nieto, R. M., Varela, M. M., et al. (2012). Natural products from Antarctic colonial ascidians of the genera Aplidium and Synoicum: variability and defensive role. Mar. Drugs 10, 1741-1764. doi: 10.3390/md10081741

Núñez-Pons, L., Forestieri, R., Nieto, R. M., Varela, M., Nappo, M., Rodríguez, J., et al. (2010). Chemical defenses of tunicates of the genus Aplidium from the Weddell Sea (Antarctica). Pol. Biol. 33, 1319-1329. doi: 10.1007/s00300-0100819-7

Núñez-Pons, L., Nieto, R. M., Avila, C., Jiménez, C., and Rodríguez, J. (2015). Mass spectrometry detection of minor new meridianins from the Antarctic colonial ascidians Aplidium falklandicum and Aplidium meridianum. J. Mass Spectrom. 50, 103-111. doi: 10.1002/jms.3502

Palermo, J. A., Rodriguez-Brasco, M. F., Spagnuolo, C., and Seldes, A. M. (2000). Illudalane sesquiterpenoids from the soft coral Alcyonium paessleri: the first natural nitrate esters. J. Org. Chem. 65, 4482-4486. doi: 10.1021/jo991740x

Pandey, A., and Yarzábal, L. A. (2019). Bioprospecting cold-adapted plant growth promoting microorganisms from mountain environments. Appl. Microbiol. Biotechnol. 103, 643-657. doi: 10.1007/s00253-018-9515-2

Park, Y. C. (2004). Chemical Investigation of Three Antarctic Marine Sponges. Graduate thesis. Tampa, FL: University of South Florida.

Pascoal, F., Magalhães, C., and Costa, R. (2020). The link between the ecology of the prokaryotic rare biosphere and its biotechnological potential. Front. Microbiol. 11:231. doi: 10.3389/fmicb.2020.00231

Patiño-Cano, L. P., Quintana Manfredi, R., Pérez, M., García, M., Blustein, G., Cordeiro, R., et al. (2018). Isolation and antifouling activity of azulene derivatives from the Antarctic gorgonian Acanthogorgia laxa. Chem. Biodivers. 15:e1700425. doi: 10.1002/cbdv.201700425

Patiño-Cano, L. P., Muniain, C., Knott, M. E., Puricelli, L., and Palermo, J. A. (2014). Bromopyrrole alkaloids isolated from the Patagonian bryozoan Aspidostoma giganteum. J. Nat. Prod. 77, 1170-1178. doi: 10.1021/np500012y

Patridge, E., Gareiss, P., Kinch, M. S., and Hoyer, D. (2016). An analysis of FDA-approved drugs: natural products and their derivatives. Drug Discov. 21, 204-207. doi: 10.1016/j.drudis.2015.01.009

Perry, N. B., Ettouati, L., Litaudon, M., Blunt, J., Munro, M., Parkin, S., et al. (1994). Alkaloids from the antarctic sponge Kirkpatrickia varialosa. Part 1: Variolin B, a new antitumour and antiviral compound. Tetrahedron 50, 3987-3992. doi: 10.1016/s0040-4020(01)89673-3

Primo, C., and Vázquez, E. (2009). Antarctic ascidians: An isolated and homogeneous fauna. Polar Res. 28, 403-414. doi: 10.1111/j.1751-8369.2009. 00110.x

Reen, F. J., Gutiérrez-Barranquero, J. A., Dobson, A. D., Adams, C., and O'Gara, F. (2015). Emerging concepts promising new horizons for marine biodiscovery and synthetic biology. Mar. Drugs 13, 2924-2954. doi: 10.3390/md13052924

Reyes, F., Fernández, R., Rodríguez, A., Francesch, A., Taboada, S., Avila, C., et al. (2008). Aplicyanins A-F, new cytotoxic bromoindole derivatives from the marine tunicate Aplidium cyaneum. Tetrahedron 64, 5119-5123. doi: 10.1016/ j.tet.2008.03.060

Riesenfeld, C. S., Murray, A. E., and Baker, B. J. (2008). Characterization of the microbial community and polyketide biosynthetic potential in the palmerolideproducing tunicate Synoicum adareanum. J. Nat. Prod. 71, 1812-1818. doi: $10.1021 / \mathrm{np} 800287 \mathrm{n}$

Rocha-Martin, J., Harrington, C., Dobson, A. D., and O’Gara, F. (2014). Emerging strategies and integrated systems microbiology technologies for biodiscovery of marine bioactive compounds. Mar. Drugs 12, 3516-3559. doi: 10.3390/ md12063516

Rodriguez-Brasco, M. F., Seldes, A. M., and Palermo, J. A. (2001). Paesslerins A and B: novel tricyclic sesquiterpenoids from the soft coral Alcyonium paessleri. Organic Let. 3, 1415-1417. doi: 10.1021/ol006684x

Ronowicz, M., Peña Cantero, A. L., Mercado Casares, B., Kuklinski, P., and Soto Àngel, J. J. (2019). Assessing patterns of diversity, bathymetry and distribution at the poles using Hydrozoa (Cnidaria) as a model group. Hydrobiologia 833, 25-51. doi: 10.1007/s10750-018-3876-5

Sacristán-Soriano, O., Angulo-Preckler, C., Vázquez, J., and Avila, C. (2017). Potential chemical defenses of Antarctic benthic organisms against marine bacteria. Polar Res. 36:1390385. doi: 10.1080/17518369.2017.1390385

Sangwan, R., Mishra, V. N., and Mandal, P. K. (2020). Synthesis of a common pentasaccharide moiety of diplasteriosides $\mathrm{A}$ and $\mathrm{B}$ belong to starfish Asterosaponins isolated from the Diplasterias brucei. Tetrahedron Lett. 61:152421. doi: 10.1016/j.tetlet.2020.152421

Sayyad, A. A., Kaim, K., and Kaliappan, K. P. (2020). Synthetic studies on palmerolide C: synthesis of an advanced intermediate towards the revised structure of palmerolide C. Organic Biomol. Chem. 18, 5937-5950. doi: 10.1039/ d0ob01140a

Seldes, A. M., Brasco, M. F., Franco, L. H., and Palermo, J. A. (2007). Identification of two meridianins from the crude extract of the tunicate Aplidium meridianum by tandem mass spectrometry. Nat. Prod. Res. 21, 555-563. doi: 10.1080/ 14786410601133517

Shilling, A., Witowski, C. G., Maschek, J., Azhari, A., Vesely, B., Kyle, D., et al. (2020). Spongian diterpenoids derived from the Antarctic sponge Dendrilla antarctica are potent inhibitors of the Leishmania parasite. J. Nat. Prod. 83, 1553-1562. doi: 10.1021/acs.jnatprod.0c00025

Shin, J., Seo, Y., Rho, J., Baek, E., Kwon, B., Jeong, T. S., et al. (1995). Suberitenones $A$ and B: Sesterterpenoids of an unprecedented skeletal class from the Antarctic sponge Suberites sp. J. Org. Chem. 60, 7582-7588. doi: 10.1021/jo00128a034

Silchenko, A. S., Kalinovsky, A. I., Avilov, S. A., Andryjashchenko, P. V., Dmitrenok, P. S., Kalinin, V. I., et al. (2013). Triterpene glycosides from Antarctic sea cucumbers IV. Turquetoside A, a 3-O-methylquinovose containing disulfated tetraoside from the sea cucumber Staurocucumis turqueti (Vaney, 1906) (= Cucumaria spatha). Biochem. Syst. Ecol. 51, 45-49. doi: 10. 1016/j.bse.2013.08.012

Solanki, H. R., Angulo-Preckler, C., Calabro, K., Kaur, N., Lasserre, P., Cautain, B., et al. (2018). Suberitane sesterterpenoids from the Antarctic sponge Phorbas areolatus (Thiele, 1905). Tetrahedron Lett. 59, 3353-3356. doi: 10.1016/j.tetlet. 2018.07.055

Soldatou, S., and Baker, B. J. (2017). Cold-water marine natural products, 2006 to 2016. Nat. Prod. Rep. 34, 585-626. doi: 10.1039/c6np00127k

Stern, M., Gierse, A., Tan, S., and Bicker, G. (2014). Human Ntera2 cells as a predictive in vitro test system for developmental neurotoxicity. Archives Toxicol. 88, 127-136. doi: 10.1007/s00204-013-1098-1

Suarez-Jimenez, G. M., Burgos-Hernandez, A., and Ezquerra-Brauer, J. M. (2012). Bioactive peptides and depsipeptides with anticancer potential: Sources from marine animals. Mar. Drugs 10, 963-986. doi: 10.3390/md10050963

Tan, A. S., and Berridge, M. V. (2000). Superoxide produced by activated neutrophils efficiently reduces the tetrazolium salt, WST-1 to produce a soluble formazan: a simple colorimetric assay for measuring respiratory burst activation and for screening anti-inflammatory agents. J. Immunol. Methods 238, 59-68. doi: 10.1016/s0022-1759(00)00156-3

Thomas, D. N., Fogg, G. E., Convey, P., Fritsen, C. H., Gili, J. M., Gradinger, R., et al. (2008). The biology of Polar Regions. Oxford: Oxford University Press, doi: 10.1093/acprof:oso/9780199298112.001.0001

Thomas, S. A., Sanchez, A., Kee, Y., Wilson, N. G., and Baker, B. J. (2019). Bathyptilones: Terpenoids from an Antarctic sea pen, Anthoptilum grandiflorum (Verrill, 1879). Mar. Drugs 17:513. doi: 10.3390/md17090513

Thomas, S. A., Von Salm, J. L., Clark, S., Ferlita, S., Nemani, P., Azhari, A., et al. (2018). Keikipukalides, furanocembrane diterpenes from the Antarctic deep sea octocoral Plumarella delicatissima. J. Nat. Prod. 81, 117-123. doi: 10.1021/acs. jnatprod.7b00732

Trimurtulu, G., Faulkner, D., Perry, N. B., Ettouati, L., Litaudon, M., Blunt, J., et al. (1994). Alkaloids from the antarctic sponge Kirkpatrickia varialosa. Part 2: Variolin A and N(3')-methyl tetrahydrovariolin B. Tetrahedron 50, 3993-4000. doi: 10.1016/s0040-4020(01)89674-5

Tripathi, A., Schofield, M. M., Chlipala, G. E., Schultz, P. J., Yim, I., Newmister, S. A., et al. (2014). Baulamycins A and B, broad-spectrum antibiotics identified as inhibitors of siderophore biosynthesis in Staphylococcus aureus and Bacillus anthracis. J. Am. Chem. Soc. 136, 1579-1586. doi: 10.1021/ja4115924

Turk, T., Ambrozic Avguštin, J., Batista, U., Strugar, G., Kosmina, R., Civović, S., et al. (2013). Biological activities of ethanolic extracts from deep-sea Antarctic marine sponges. Mar. Drugs 11, 1126-1139. doi: 10.3390/md11041126

Upadhyay, P., Shrivastava, R., and Agrawal, P. K. (2016). Bioprospecting and biotechnological applications of fungal laccase. 3 Biotech. 6:15. doi: 10.1007/ s13205-015-0316-3

Urban, S., Wilton, H., Lu, C. C., and Capon, R. J. (1995). A New sesquiterpene alcohol from an Antarctic sponge. Nat. Prod. Lett. 6, 187-192. doi: 10.1080/ 10575639508043157 
von Salm, J. L., Wilson, N. G., Vesely, B. A., Kyle, D. E., Cuce, J., and Baker, B. J. (2014). Shagenes A and B, new tricyclic sesquiterpenes produced by an undescribed Antarctic octocoral. Organic Let. 16, 2630-2633. doi: 10.1021/ ol500792x

von Salm, J. L., Witowski, C. G., Fleeman, R., McClintock, J. B., Amsler, C., Shaw, L., et al. (2016). Darwinolide, a new diterpene scaffold that inhibits methicillinresistant Staphylococcus aureus biofilm from the Antarctic sponge Dendrilla membranosa. Org. Lett. 18, 2596-2599. doi: 10.1021/acs.orglett.6b00979

Wang, W., and Namikoshi, M. (2007). Bioactive nitrogenous metabolites from ascidians. Heterocycles 74, 53-88. doi: 10.3987/rev-07-sr(w)2

Waters, A. L., Hill, R. T., Place, A. R., and Hamann, M. T. (2010). The expanding role of marine microbes in pharmaceutical development. Curr. Opin. Biotechnol. 21, 780-786. doi: 10.1016/j.copbio.2010.09.013

Yang, A., Baker, B. J., Grimwade, J., Leonard, A., and McClintock, J. B. (1995). Discorhabdin alkaloids from the Antarctic sponge Latrunculia apicalis. J. Nat. Prod. 58, 1596-1599. doi: 10.1021/np50124a020
Zubía, E., Ortega, M. J., and Salvá, J. (2005). Natural products chemistry in marine ascidians of the genus Aplidium. Mini Rev. Organ. Chem. 2, 389-399. doi: 10.2174/157019305774 322707

Conflict of Interest: The authors declare that the research was conducted in the absence of any commercial or financial relationships that could be construed as a potential conflict of interest.

Copyright (C) 2021 Avila and Angulo-Preckler. This is an open-access article distributed under the terms of the Creative Commons Attribution License (CC BY).

The use, distribution or reproduction in other forums is permitted, provided the original author(s) and the copyright owner(s) are credited and that the original publication in this journal is cited, in accordance with accepted academic practice. No use, distribution or reproduction is permitted which does not comply with these terms. 